\title{
WORK-FAMILY RECONCILIATION POLICIES AND WOMEN'S AND MOTHERS' LABOR MARKET OUTCOMES IN RICH DEMOCRACIES
}

\author{
David Brady \\ University of California, Riverside \& WZB Berlin Social Science Center \\ Agnes Blome \\ Free University of Berlin \\ Julie A. Kmec \\ Washington State University
}

Forthcoming in Socio-Economic Review

November 14, 2018

Word Count: 10,512

* We thank SER Reviewers and Editors, Irene Boeckmann, Janet Gornick, Lena Hipp, Martha Stinson, Marion Obermaier, and audiences at the 2014 Association of Public Policy Analysis and Management Fall Research Conference, and the Sociology Department at the University of Missouri. Direct correspondence to David Brady, School of Public Policy, University of California, Riverside, INTS 4133, 900 University Ave., Riverside, CA, 92521; dbrady@ucr.edu. 


\title{
WORK-FAMILY RECONCILIATION POLICIES AND WOMEN'S AND MOTHERS' LABOR MARKET OUTCOMES IN RICH DEMOCRACIES
}

\begin{abstract}
Prominent research has claimed that work-family reconciliation policies trigger "tradeoffs" and "paradoxes" in terms of gender equality with adverse labor market consequences for women. These claims have greatly influenced debates regarding social policy, work, family, and gender inequality. Motivated by limitations of prior research, we analyze the relationship between the two most prominent work-family reconciliation policies (paid parental leave and public childcare coverage) and seven labor market outcomes (employment, full-time employment, earnings, fulltime earnings, being a manager, being a lucrative manager, and occupation percent female). We estimate multi-level models of individuals nested in a cross-section of 21 rich democracies near 2005, and two-way fixed effects models of individuals nested in a panel of 12 rich democracies over time. The vast majority of coefficients for work-family policies fail to reject the null hypothesis of no effects. The pattern of insignificance occurs regardless of which set of models or coefficients one compares. Moreover, there is as much evidence that significantly contradicts the "tradeoff hypothesis" as is consistent with the hypothesis. Altogether, the analyses undermine claims that work-family reconciliation policies trigger tradeoffs and paradoxes in terms of gender equality with adverse labor market consequences for women.
\end{abstract}

SER keywords: work, family, labor markets, social policy, inequality, welfare state JEL Classification: J, H, I 
In recent decades, many rich democracies expanded work-family reconciliation policies designed to alleviate gender-based labor market inequalities. Large cross-national and historical variation now exist in the two most prominent work-family policies: paid parental leave and publicly subsidized childcare (Ferrarini 2006; Morgan 2006). For example, since the 1970s, Norway has offered lengthy paid parental leaves and steadily expanded publicly subsidized childcare (Petersen et al. 2014). By contrast, there is no public mandate for paid leave in the U.S., and there is little public funding for childcare. While Germany historically has had large gender inequalities in employment (Korpi et al. 2013), it reformed work-family policies in the mid2000s to greatly expand paid parental leave and publicly subsidize childcare (Blome 2017). A rich literature exists on the relationship between this cross-national variation in workfamily reconciliation policies and women's and mothers' attainment. Many provide evidence that generous work-family policies encourage female and maternal employment (Ferrarini 2006; Gornick et al. 1997; Gornick and Meyers 2003b; Petersen et al. 2014; Pettit and Hook 2005; Thévenon and Solaz 2015), reduce motherhood penalties (Budig et al. 2012; Gornick et al. 1998; Misra et al. 2011; Waldfogel 1998), and have spillover effects on other dimensions of gender equality (Cooke and Baxter 2010; Gornick and Meyers 2008; Korpi 2000; Korpi et al. 2013; McDonald 2006, 2013; Misra et al. 2007; Ray et al. 2010).

In contrast to these optimistic studies, highly influential recent research has problematized generous work-family reconciliation policies for triggering gender "tradeoffs" and "paradoxes" with adverse labor market consequences for women (Albrecht et al. 2003; Bergmann 2009; Gasser and Liechti 2015; Lalive and Zweimueller 2009; Mandel and Semyonov 
2005, 2006; Pettit and Hook 2009; Schoenberg and Ludsteck 2014). ${ }^{1}$ According to these scholars, lengthy paid parental leaves, public childcare, and large welfare states and public sectors undermine women's and mothers' labor market outcomes. On balance, this literature often acknowledges some benefits of moderate work-family policies. However, this critical account of tradeoffs and paradoxes has attracted a great deal of attention about the potentially counterproductive or inegalitarian consequences of generous work-family policies.

Taking the literature on paradoxes and tradeoffs as a point of departure, we address the following research questions: To what extent are work-family policies related to women's labor market outcomes? Are these policies differently related to the labor market outcomes of women versus men and mothers versus childless women? We analyze the relationship between the two most prominent work-family policies (paid parental leave length and publicly subsidized childcare coverage) and seven labor market outcomes. We build on existing work by incorporating a variety of analytical advances: more recent and updated data; better measurement; both cross-national and over-time variation; more labor market outcomes; and, comparisons between women and men and between mothers and childless women.

Altogether, these advances provide new leverage for understanding the labor market consequences of work-family policies. By incorporating all of these advances, ours is perhaps the most comprehensive analysis of the consequences of work-family policies to date. More than simply replicating and updating prior work, we offer novel contributions for understanding the relationship between work-family policies and gender-based labor market inequality. To preview

\footnotetext{
${ }^{1}$ The literature refers to both paradoxes and tradeoffs. The terms paradoxes/tradeoffs represent the same phenomena and refer to a broad set of negative women's labor market outcomes that result from auspiciously generous work-family policies. When discussing past studies, we use their terms. However, we later simply refer to the "tradeoff hypothesis."
} 
our results, we find that the vast majority of coefficients for work-family policies fail to reject the null hypothesis of no effects. In sum, the analyses undermine claims that work-family reconciliation policies trigger tradeoffs and paradoxes in terms of gender equality with adverse labor market consequences for women.

\section{THE PARADOXES AND TRADEOFFS HYPOTHESIS}

Although not the first or only critical perspective on work-family policies, our review devotes special attention to the particularly influential work of Mandel and Semyonov and Pettit and Hook. ${ }^{2}$ In a series of articles, Mandel and Semyonov $(2005,2006)$ made the case that extensive work-family policies undermine women's earnings and occupational attainment (also Mandel 2012; Mandel and Shalev 2009). They contended that, while perhaps work-family policies increased women's labor force participation, they encouraged employer discrimination, the emergence of glass ceilings, and workplace sex segregation. They studied roughly 20 rich democracies with LIS data, measuring work-family policies with a "welfare state index" composed of the number of fully paid weeks of maternity leave, the percent of pre-school aged children in public childcare, and the public share of the country's workforce. ${ }^{3}$ They estimated multi-level models of individual women and men aged 25-60 nested in country-level contexts of work-family policies, and examined employment and earnings (Mandel and Semyonov 2005),

\footnotetext{
${ }^{2}$ According to Google Scholar, Mandel's and Semyonov's contributions have been cited more than 1,000 times. The key contributions by Pettit and Hook have been cited more than 420 times. ${ }^{3}$ Mandel and Semyonov (2006: 1937) argued "the index effectively captures a broad phenomenon of 'mother-friendliness' which transcends individual policies....it is welfare state 'interventionism' more than discrete and specific interventions which fuels the mechanisms that undermine women's job opportunities."
} 
part- and full-time employment, managerial and lucrative managerial attainment, and employment in female-typed occupations (Mandel and Semyonov 2006).

To test whether work-family policies trigger paradoxes, they estimated cross-level interactions between their country-level welfare state index and individual-level sex. If the welfare state index interacts positively with being male (or negatively with being female), this demonstrated gender inequality. Although the interaction between the welfare state index and being male did not reach statistical significance (Mandel and Semyonov 2005), they interpreted the positive sign of the interaction as evidence of a paradox. Also, they found that the length of maternity leave specifically enhances male earnings relative to female earnings (p.963). In 2006, Mandel and Semyonov reported that the welfare state index is positively associated with women's labor force participation relative to men's. However, relative to men, the welfare state index is negatively associated with women's attainment of managerial and lucrative managerial positions and positively associated with women's presence in female-typed occupations.

Pettit and Hook (2009) critiqued work-family policies for causing "inclusion-equality tradeoffs" - contradictions between women's opportunities to enter the labor market, and inequalities within the labor market and domestic labor. Consistent with Mandel and Semyonov, Pettit and Hook (2009) showed that maternity leave, part-time employment, and public childcare are positively associated with women's employment while parental leave had no effect. Nevertheless, Pettit and Hook argued that long parental leaves and extensive part-time employment worsen gender inequality. They showed that a greater prevalence of part-time work is negatively associated with women's hourly wages. Moreover, the wage benefits of being highly educated are weaker and the costs of children greater where part-time work is prevalent and parental leave is available. In most countries, women face tradeoffs that lead to greater 
childrearing and domestic labor, gender specialization at home and work, and exclusion from the best labor market opportunities. For example, Pettit and Hook found having young children was negatively associated with women's employment in countries with parental leave, and having children was negatively associated with female employment in countries with a higher prevalence of part-time work. Pettit and Hook (2009) concluded that high female employment correlates with high occupational sex segregation and high levels of female part-time work. In contrast to Mandel and Semyonov, Pettit and Hook concluded that only public childcare encourages both gender equality and inclusion.

An extensive literature beyond these seminal works has fueled the debate on paradoxes and tradeoffs (Bergmann 2009; Dieckhoff et al. 2015; Kluve and Tamm 2013; Lalive and Zweimueller 2009; Morgan and Zippel 2003; Mun and Jung 2018; Nieuwenhuis et al. 2017; Ziefle and Gangl 2015). For brevity, we review only a sample. Consistent with claims of employer discrimination against women in countries with generous leaves, scholars have shown that Scandinavian countries tend to have high levels of occupational sex segregation (Charles and Grusky 2004). Much literature has scrutinized whether long parental leaves undermine women's careers (Morgan and Zippel 2003; Nieuwenhuis et al. 2017). For example, Aisenbrey and colleagues (2009) found that in countries such as Sweden and Germany, long leaves hurt mothers' career attainment (also Evertsson and Duvander 2010; but see Keck and Saraceno 2013). Partly because long leaves often come with low or no wage replacement, few men take up the leaves and they subsequently avoid childcare responsibilities. Further, long leaves appear to encourage a gendered division of domestic labor, which then worsens gender inequality in the labor market (Hook 2010). Relatedly, Gangl and Ziefle (2015) concluded that extensions of parental leave in Germany weakened mothers' subjective commitment to work relative to her 
subjective commitment to family. Similarly, Schoenberg and Ludsteck (2014) found that expansions of German parental leave reduced mothers' post-birth employment (also Lalive and Zweimueller 2009).

Similar to Pettit and Hook, many earlier studies concluded that public childcare increases women's and maternal employment (Baker et al. 2008). However, other studies find heterogeneous or insignificant effects. For example, while Bauernschuster and Schlotter (2015) found that the expansion of public childcare places in Germany was positively associated with maternal employment, Havnes and Mogstad (2011) analyzed the introduction of subsidized universal childcare in Norway in the late 1970s and find no effects on mothers' employment. Other studies found employment effects only for specific groups of mothers (e.g. single mothers, mothers without additional very young children, mothers of older children, etc.) (Goux and Maurin, 2010; Cascio, 2009).

\section{LIMITATIONS OF PRIOR RESEARCH}

Despite influential contributions on paradoxes and tradeoffs, the literature is constrained by a number of limitations. This section outlines those limitations, and explains how the literature is evolving, pointing out where progress has occurred since the initial studies. Again highlighting the seminal work of Mandel and Semyonov and Pettit and Hook, we organize our discussion into five major points.

First, the literature has often used questionable measures of work-family policies. Although Mandel and Semyonov's welfare state index combined several indicators, a growing consensus advocates for analyzing specific work-family policies separately (cf. Budig et al. 2012; Korpi et al. 2013; Misra et al. 2011; Pettit and Hook 2009). As Boeckmann and colleagues 
(2015) have stressed, different work-family policies are likely to have "divergent impacts" on women's and mothers' employment. For example, while Hook (2010) showed long leaves exacerbate gender inequalities in domestic labor, public childcare reduces women's time spent on cooking. Indeed, many have shown that public childcare facilitates women's employment continuity (Steiber and Haas 2012). To be clear, by combining the different measures in one index, Mandel and Semyonov $(2005,2006)$ treated the different policies as having the same effects. Indeed, they even decomposed their index in an effort to demonstrate this. However, upon close inspection, their own results do not demonstrate that parental leave and public childcare have similar effects. ${ }^{4}$ Relatedly, some have failed to distinguish between paid and unpaid leave. Pettit and Hook (2009) and Hook (2010) measured leave as the sum of the maximum number of paid or unpaid weeks even though paid leave is likely to have different consequences than unpaid leave (Boeckmann et al. 2015; Gornick and Meyers 2008). For example, Schober (2014) showed that Germany's 1992 extension of unpaid leave worsened gender inequality in domestic labor while the 2007 extension of paid leave alleviated it.

Second, the literature has focused more on gaps between women and men without fully scrutinizing gaps between mothers and childless women (see Nieuwenhuis et al. 2017). Yet work-family policies are designed to facilitate mothers' employment as much as to alleviate sex inequalities (Gornick et al. 1998; Gornick and Meyers 2003b, 2008). Indeed, others illustrated

\footnotetext{
${ }^{4}$ In their Appendix A2, Mandel and Semyonov (2006) do not find robust results for the components of their index. The length of maternity leave and public sector employment heighten women's labor force participation relative to men, but childcare does not significantly interact with being female. All three components are significantly negatively associated with women's managerial attainment relative to men's, but only maternity leave is significantly negatively associated with women's lucrative managerial attainment relative to men's. Maternity leave and public sector employment are significantly positively associated with women's presence in female-typed occupations relative to men's, but the cross-level interaction between childcare and being female is not significant.
} 
how work-family policies shape cross-national variation in motherhood penalties (Abendroth et al. 2014; Boeckmann et al. 2015; Budig et al. 2012; Nieuwenhuis 2014; Petersen et al. 2010). Petersen and colleagues (2014) showed that generous work-family policies almost entirely eliminated the Norwegian motherhood penalty by the mid-1990s. Comparing the U.K. and U.S., Waldfogel (1998) found paid leave encouraged women to return to work after childbirth, and this contributed to a wage premium that offset any negative effect of children on wages.

Third, the multi-level models utilized in the literature are sensitive to the number of countries (i.e. level-2 units) and cross-level interactions (Bryan and Jenkins 2016). Studies in this literature typically feature 15-20 countries, which could be a sufficient number of level-2 units for a parsimonious set of country-level variables in a random intercept model (Stegmueller 2013; but see Bryan and Jenkins 2016). However, past studies typically included several cross-level interactions and several country-level variables (Korpi et al. 2013). In Mandel and Semyonov (2006) analyses of 19-22 countries, they included four country-level variables in the random intercept equation, and multiple cross-level interactions with the random slope for sex.

Yet, estimating many cross-level interactions with relatively few level-2 units could be beyond the capacity of these models (Stegmueller 2013). This could explain why many of the key interactions between country-level policies and individual-level sex are insignificant, contrary to their hypotheses, or not robust. For example, of the 10 reported cross-level interactions between the welfare state index and sex in Mandel and Semyonov (2005), only 2 were statistically significant. While Mandel and Semyonov (2005) found that longer paid leaves worsen the gap between men's and women's earnings, they presented no evidence that public childcare, public employment, or their welfare state index significantly influence men's earnings relative to women's. Pettit and Hook (2009) used a two-step estimator that arguably better 
incorporates cross-level interactions. However, their random intercept equations include as many as ten country-level variables despite as few as 29 country-years. Many key predictors were insignificant. For example, long parental leaves did not worsen the employment penalty associated with having more children. Also, contrary to their tradeoff, they found that longer parental leaves alleviate the positive effect of having a young child for part-time employment.

Fourth, most analyses in the literature are cross-sectional. In these cross-sectional analyses, there could be unobserved differences between countries that are associated with workfamily policies and/or labor market outcomes. If this is the case, coefficients for work-family policies will be biased. While it is unlikely that one can fully eliminate all omitted confounding variables, longitudinal data enable inclusion of country fixed effects that absorb stable differences between countries. To the best of our knowledge, relatively few cross-national studies include panel data or fixed effects (Abendroth et al. 2014; Dieckhoff et al. 2015; Nieuwenhuis et al. 2017), even though Pettit and Hook (2009) included multiple survey waves for several countries. At the same time, fairly universal cultural and historical changes have shaped gender inequality cross-nationally. As Petersen and colleagues (2014: 1445) remarked, there have been "broad cultural transformations over the last 40 years concerning the role men take in the family and both household work and caring for children." Such universal historical changes can be accounted for with period fixed effects that help eliminate mistakenly attributing universal improvements in gender equality to expanding work-family policies.

While the cross-national literature has mainly been cross-sectional, several case studies of individual countries exploit over-time change in work-family policies (Lalive and Zweimueller 2009; Mun and Jung 2018; Petersen et al. 2010, 2014; Schober 2014; Schoenberg and Ludsteck 2014). For example, Gangl and Ziefle (2015) used difference-in-difference models to compare 
German mothers' subjective preferences immediately before and after work-family policy reforms. Although these longitudinal studies tend to concentrate on one country, their scrutiny of within-country over-time variation provides a useful model for cross-national research as well.

Finally, most of the highlighted studies used relatively old data. Mandel and Semyonov's 2005 and 2006 articles include LIS datasets from 1991-2000, while Pettit and Hook (2009) primarily use LIS data from the 1980s and 1990s. To be clear, the authors used data that were available at the time. However, the quality and standardization of variables in these datasets were limited and subsequently improved when the LIS underwent a major revision in $2011 .{ }^{5}$ For example, occupation was not standardized in earlier LIS datasets and was often missing. Most likely because of limitations in the LIS at the time, Pettit and Hook (2009) collapsed occupation into five broad categories. Mandel and Semyonov's (2005) approach to address the lack of necessary occupation data is unclear. ${ }^{6}$

Another particularly important limitation of prior LIS-based studies concerns the availability of standardized data on hourly wages. Pettit and Hook (2009) estimated hourly wages by using data on pre-tax annual wages for some countries and post-tax annual wages for

\footnotetext{
${ }^{5}$ On the improvement, see http://www.lisdatacenter.org/wp-content/uploads/our-lisdocumentation-restructuring.pdf. For details on what variables are actually non-missing in any LIS dataset, see the "Variable Availability Matrix" at http://www.lisdatacenter.org/our-data/lisdatabase/documentation/. For example, in the revised LIS data, two-digit occupation data is available for Denmark in 1992, 2004, 2007, and 2010, but not 1995 or 2000.

${ }^{6}$ Their 2005 article's Table 4 (p.962) noted that six countries, including Denmark, were omitted because they "do not have data on female-typed occupations at the individual level." However, their footnote 2 on p. 954 stated: "For Denmark, we computed the segregation variables [i.e. female-typed occupation] using the LIS data." The absence or availability of Danish occupation data is also unclear because they (2005: 962, model 3) omitted only Denmark from a model including a control for managerial position. Although the 2005 article did not clarify what data was needed for their female-typed occupation variable, their 2006 article (p. 1919) suggested two-digit occupation data is needed. However, their 2006 article included female-typed occupation data for 19 countries while their 2005 article only had data for 14 countries.
} 
other countries. The annual wages data was from the prior year, but it was standardized by a combination of usual hours worked per week from the current year and number of weeks worked in the prior year. Mandel and Semyonov (2005) reported controlling for weekly hours worked, however, the necessary data is not actually available for several countries in the LIS. ${ }^{7}$ Ultimately, we conclude it is not possible to consistently measure hourly wages in the LIS: a) because of systematic missingness within countries on usual hours worked and number of weeks worked and; b) because several countries simply do not have data on hours or weeks worked or even full- and part-time status (Korpi et al. 2013).

In sum, the literature on paradoxes and tradeoffs has been constrained by at least five limitations. For this area to advance, it is essential to: a) analyze work-family policies separately; b) compare mothers versus childless women and women versus men; c) estimate parsimonious multi-level models; d) incorporate over-time variation and control for fixed effects for countries and time; and, e) use more recent LIS data with greater transparency.

\section{METHODS}

Our analyses are based on the Luxembourg Income Study (LIS). The LIS is an archive of individual-level nationally-representative cross-sectional datasets from several dozen countries. The LIS cleans and harmonizes the data and creates a new set of standardized variables. The LIS

\footnotetext{
${ }^{7}$ In their footnote 2 (p. 954), they explain: "Because Denmark and Norway do not provide information on weekly working hours in the LIS data, we use the following external sources for these two countries: the Danish Leisure Study (1993) and the Norwegian Level of Living Survey (1995)." To the best of our knowledge, it is not possible to merge datasets onto the LIS. One can imagine they could have used these datasets to construct models of how to impute hours, and then imputed hours within the LIS from variables available in both datasets. However, the article does not provide any information beyond that footnote. Their 2006 article includes Denmark and only reports: "Data for Norway were based on the Norwegian Level of Living Survey 1995" (p.1918, footnote 6).
} 
advantageously has a large number of rich countries, cross-national comparability, high quality, national representativeness, and large samples.

Like prior research, we focus on high income ("rich") stable democracies. We include every rich democracy in the LIS with individual-level data on employment, occupation, education, and earnings. Because of these requirements, we cannot include all the rich democracies. ${ }^{8}$ For the cross-sectional analyses, we include a dataset for each country as close to 2005 as possible. This time period is recent enough to incorporate the most substantial workfamily policy reforms in these countries. However, it is also early enough to avoid confounding with the Great Recession. For some analyses of full-time workers, we omit countries that lack data on full-time status. Altogether, the mid-2000s cross-section includes 21 countries: Austria (2004), Belgium (2000), Canada (2004), the Czech Republic (2004), Denmark (2004), Estonia (2004), Finland (2004), France (2005) Germany (2007), Greece (2004), Hungary (2005), Ireland (2007), Israel (2005), Luxembourg (2004), the Netherlands (2004), Slovenia (2004), South Korea (2004), Spain (2004), Sweden (1995), the U.K. (2004), and the U.S. (2004). ${ }^{9}$

We also use panel techniques on repeated cross-sections from countries with data available from the 1980 and 2000s. Again, requiring data on employment, occupation, education, and earnings limits the number of countries. For this reason, we use a few datasets from the 1990s (rather than the 1980s). Still, we are able to include at least a moderate time period

\footnotetext{
${ }^{8}$ For example, we omit Australia because of difficulties differentiating between high and medium education levels. We omit Switzerland because individual-level data on earnings is not available, and we exclude Italy (see http://www.lisdatacenter.org/our-data/lis-database/bycountry/italy-2/) and Norway (see http://www.lisdatacenter.org/our-data/lis-database/bycountry/norway-2/) because occupation data is not available.

${ }^{9}$ Unfortunately, recent Swedish datasets lack occupational data. Therefore, we were forced to go back to 1995 to include a Swedish dataset with occupational data. Similarly, 2000 is the most recent dataset available for Belgium.
} 
between waves to allow for over-time variation in work-family reconciliation policies. The panel includes 12 countries: Austria $(1994,2004)$ Canada $(1987,2004)$, Denmark $(1987,2004)$, Finland (1987, 2004), France (1984, 2005), Germany (1984, 2007), Ireland (1994, 2007), Israel (1986, 2007), Luxembourg $(1985,2004)$, the Netherlands (1990, 2004), Spain $(1990,2004)$, and the U.S. $(1986,2004)$.

Our analyses include all individuals aged $25-54$ years old as this is the prime working age in rich democracies (Korpi et al. 2013). When appropriate, some models include all workingaged, others include only the employed, and some include only full-time employed. Some analyses focus only on women, and others pool men and women. The tables below detail the samples. Appendix I includes the definitions and sources of the variables. Appendix II includes descriptive statistics.

\section{Dependent Variables}

Uniquely, we comprehensively analyze a broad variety of seven labor market outcomes. Our first outcome, annual earnings, is total labor market income from all employment in a given year. To adjust for cross-national differences in currency and inflation, we follow previous research and convert annual earnings to country-specific percentiles (Mandel and Semyonov 2005). This means earnings is measured as relative rank within each country's distribution of employed 25-54 year old women and men. Therefore, even when models only include women, this variable tracks their standing relative to other men and women. Annual earnings combine pay and quantity of hours, both of which are relevant to evaluating work-family policies (Misra 
et al. 2011). ${ }^{10}$ Second, we examine full-time annual earnings, also measured in percentiles of 25 54 year olds, but only for full-time workers (and 19 of 21 countries).

Next, employment is a binary variable coded 1 if a respondent is employed and 0 if not. Because part- versus full-time employment have different implications, we assess a binary variable for full-time employment, which is available for 19 of the 21 countries. To define fulltime, we first use the LIS definition of full-time. When that was unavailable, we supplemented it with measures of those working 35 or more hours per week; or those full-time employed more than 29 weeks and part-time employed less than 21 weeks in a year. ${ }^{11}$

The fifth outcome, manager, is a binary measure coded 1 if a respondent is a manager and 0 if not. To code managers, we use the LIS one- and two-digit occupation data. Because managerial titles do not necessarily indicate authority and status (Mandel and Semyonov 2006), our sixth outcome identifies those with managerial titles who are also well-compensated: lucrative managers. We coded this binary measure 1 if a respondent is a manager and in the top $30 \%$ of the annual earnings distribution. Our seventh outcome, occupation percent female, is the percent of women in a respondent's one-digit occupation. Of course, two- or three-digit occupational percent female would be preferable. Unfortunately, however, only one-digit occupation data is available for many countries in the LIS.

\section{Work-Family Policies}

\footnotetext{
${ }^{10}$ Ideally we would also examine hourly wages, which would compare earnings while holding work time constant. Unfortunately, the LIS data on hours (and weeks) worked is not available for enough countries nor is it sufficiently cross-nationally reliable when available.

${ }^{11}$ Our approach differs from Pettit and Hook (2009), who measured full-time as 30 hours per week, which we view as too low. We also differ from Mandel and Semyonov (2006: 1918), who defined full-time as "more than 39 weekly hours." This value is too high as many countries legally define full-time at lower levels (e.g. France, Germany).
} 
We focus on the policies that arguably capture the most meaningful differences between countries and that have reliable data for all countries and years. Because different work-family reconciliation policies may have divergent effects (Boeckmann et al. 2015), we do not create a scale of work-family reconciliation policies (cf. Mandel and Semyonov 2005, 2006). Unfortunately, data unavailability and inconsistency prevent us from incorporating a wider variety of aspects of these policies - e.g., precise replacement rates for each time point during leave, take-up rates, childcare entitlements (Ray et al. 2010; Korpi et al. 2013).

The first policy is paid parental leave measured as the number of weeks of paid postdelivery maternity and parental leave available to mothers. The leave measure combines maternity and parental leave available to the mothers, and includes any level payment (regardless of replacement rate). This measure includes shareable leave but excludes leave available only to fathers. We also include paid leave squared to test for a nonlinear relationship with labor market outcomes. Childcare coverage is the percent of children under three years old in a country covered by publicly subsidized childcare. ${ }^{12}$

As Table 1 shows, work-family reconciliation policies vary considerably across countries. In the mid-2000s, the length of paid leave varies from zero (U.S., Greece) to 156 weeks (Czech Republic, Estonia, Finland, France and Hungary), and the percent of children in publicly subsidized childcare varies between 1 (U.S) and 57.1 percent (Denmark). Many countries have also changed substantially across time periods. For example, Germany went from providing 26 weeks of paid leave in 1984 to 52 weeks in 2007. Between 1987 and 2004, Canada

\footnotetext{
12 Publicly-subsidized does not necessarily have to be publicly-managed. We concentrate on childcare coverage rates for children who are under 3 years old, because in most OECD countries there is some kind of care and education provision for most children over three years old (see e.g. Multilinks Database). Because of difficulties measuring this variable in Israel (see Table 1), we re-estimated all models without Israel and found similar results.
} 
increased from 15 to 50 weeks of paid leave, and Denmark increased from 24 weeks in 1987 to 46 in 2004. The share of children in publicly subsidized childcare increased from 2 percent in 1990 in the Netherlands to 14.5 percent in 2004, and in France it increased from 20 percent in 1984 to 42 percent in 2005 . Equally notable, several countries made no substantial changes to these work-family policies over time.

\section{[ TABLE 1 ABOUT HERE ]}

\section{Other Independent Variables}

Following and extending prior research, all models control for several demographic characteristics of the respondent and his/her household. ${ }^{13}$ Education is measured using a set of binary variables drawing on the standardized LIS measure of education coded: low education (lack of a secondary school degree), medium education (the reference, e.g. high school degree in the U.S.), and high education (college degree or higher). Marital status is measured with a binary variable coded 1 if a respondent is currently married and 0 if not. Models include age in years and its square. All models control for the presence of a child under 5, and some control for the number of children. Other employment is a binary measure coded 1 if someone else in the household is employed and 0 if not.

In some models, we estimate cross-level interactions to assess whether the impact of policies on outcomes differs for mothers (versus non-mothers) and women (versus men). Hence,

\footnotetext{
${ }^{13}$ While prior studies included most of these individual-level controls, we go beyond previous research. For example, in contrast to Mandel and Semyonov (2005, 2006), we use a finer-grained measure of education, include age-squared, and a measure of whether another household member is employed. Although others have noted differences between the public and private sector for gender labor market inequality (Korpi et al. 2013), there are simply too few LIS country-years with data on the public sector to incorporate into the analysis.
} 
we include a binary variable coded 1 for mother if there are any children in the household and 0 if not. In models including both women and men, female is coded 1 and male 0 .

In addition to individual-level variables, we include two country-level variables in several models. First, the unemployment rate is the percent of the labor force without employment in a given year, which captures differences in the business cycle and economic performance. Second, wage coordination measures qualitative differences in labor market institutions and corporatism, and varies from 1 (fragmented wage bargaining) to 5 (centralized bargaining). While wage coordination is highly correlated with, and proxies, other labor market institutions like unionization, data on it is available for more countries. As discussed above, including additional country-level variables may exhaust precious degrees of freedom in multi-level models (Stegmueller 2013). We include these two because it is plausible that work-family policies may be confounded with economic performance and labor market institutions. Nevertheless, the results are entirely consistent if we omit these two country-level variables, and therefore we only present the models including these variables (see also endnotes 14-15). As detailed above, our country-level specification is more conservative than prominent prior research. ${ }^{14}$

\section{Analytic Strategy}

For each dependent variable, we estimate three models using two different approaches. We first explain the six models, and then justify the value of having both approaches. Throughout, the models are linear for continuous outcomes and logit for binary outcomes.

\footnotetext{
${ }^{14}$ As explained above, Mandel and Semyonov (2006) analyzed 19-22 countries, but included four country-level variables in the random intercept equation, and multiple cross-level interactions with the random slope for sex. Pettit and Hook (2009)'s random intercept equations include as many as ten country-level variables despite as few as 29 country-years.
} 
The first three models use samples of individuals nested in the cross-section of 21 countries in the mid-2000s. First, we estimate a random intercept multi-level model of women nested in countries. This model assesses whether work-family policies are associated with women's attainment net of individual- and country-level controls. For the continuous outcomes, the dependent variable $\mathrm{Y}_{\mathrm{ij}}$ for the $i$ th woman in the $j$ th country is a function of country intercepts $\left(\beta_{0 \mathrm{j}}\right)$, a set of individual-level fixed coefficients $\left(\beta \mathrm{X}_{\mathrm{ij}}\right)$, and an error term $\left(\varepsilon_{\mathrm{ij}}\right)$ :

$$
Y_{i j}=\beta_{0 j}+\beta X_{i j}+\varepsilon_{i j}
$$

Each country intercept $\left(\beta_{0 \mathrm{j}}\right)$ is estimated as a function of an intercept $\left(\gamma_{00}\right)$, country-level workfamily policies $\left(\gamma \mathrm{WF}_{\mathrm{j}}\right)$, other country-level controls $\left(\gamma \mathrm{Z}_{\mathrm{j}}\right)$, and an error term $\left(\mathrm{u}_{\mathrm{j}}\right)$ :

$$
\beta_{0 j}=\gamma_{00}+\gamma \mathrm{WF}_{\mathrm{j}}+\gamma \mathrm{Z}_{\mathrm{j}}+\mathrm{u}_{0 \mathrm{j}}
$$

The second model (also women only) incorporates a random intercept and a random coefficient for being a mother. In the third model, we include both men and women and incorporate a random intercept and a random coefficient for female. In these random coefficient models, we allow the coefficient for being a mother or being female to vary across countries and predict that slope $\left(\beta \mathrm{X}_{\mathrm{ij}}\right)$ as a function of the three country-level work-family policies variables $\left(\gamma \mathrm{WF}_{\mathrm{j}}\right)$, and an error term $\left(\mathrm{u}_{0 \mathrm{j}}\right)$ :

$$
\beta \mathrm{X}_{\mathrm{ij}}=\gamma_{00}+\gamma \mathrm{WF}_{\mathrm{j}}+\mathrm{u}_{0 \mathrm{j}}
$$

Thus, the second model assesses if paid leave and childcare coverage are associated with mothers' relative attainment compared to non-mothers, net of any effects of work-family policies on non-mothers. The third model assesses whether work-family policies are associated with 
women's attainment relative to men's, net of any effects of work-family policies on men. For the sake of parsimony at level 2 , the second and third models omit the country-level controls $\left(\beta Z_{\mathrm{jt}}\right)^{15}$

The next three models draw on samples of individuals nested in the panel of 12 countries.

In the fourth model, we estimate a two-way fixed effects (FE) model of women:

$$
Y_{i j t}=\beta_{0}+\beta X_{i j t}+\beta W F_{j t}+\beta Z_{j t}+\beta C_{j}+\beta D_{t}+\varepsilon_{i j}
$$

$\mathrm{Y}_{\mathrm{ijt}}$ for individual $i$, in country $j$, and decade $t . \mathrm{Y}_{\mathrm{ijt}}$ is a function of a constant $\left(\beta_{0}\right)$, individuallevel characteristics $\left(\beta \mathrm{X}_{\mathrm{ijt}}\right)$, country-level work-family policies $\left(\beta \mathrm{WF}_{\mathrm{jt}}\right)$, country-level controls $\left(\beta Z_{j t}\right)$, country dummies $\left(\beta C_{j}\right)$, and decade dummies $\left(\beta D_{t}\right)$ for the $1990 \mathrm{~s}$ and $2000 \mathrm{~s}$. Because individuals within country-years are not independent, we also cluster the standard errors by country. Because the country dummies difference out any stable differences between countries, these models estimate the relationship between within-country temporal variation in work-family policies and labor market outcomes. The decade dummies remove the generic change over time shared across countries (e.g., universal improvements in gender equality).

In the fifth model (only women) and the sixth model (men and women), we estimate twoway FE models including a set of interaction terms to assess whether the effects of work-family policies differ for mothers and non-mothers and women and men, respectively. The two-way FE models with interactions can be presented as:

$$
\mathrm{Y}_{\mathrm{ijt}}=\beta_{0}+\beta \mathrm{WF}_{\mathrm{jt}} * \mathrm{M}_{\mathrm{ijt}}+\beta \mathrm{X}_{\mathrm{ijt}}+\beta \mathrm{WF}_{\mathrm{jt}}+\beta \mathrm{C}_{\mathrm{j}}+\beta \mathrm{C}_{\mathrm{j}}^{*} \mathrm{M}_{\mathrm{ijt}}+\beta \mathrm{D}_{\mathrm{t}}+\varepsilon_{\mathrm{ij}}
$$

\footnotetext{
${ }^{15}$ In other analyses, we omitted paid leave squared in the random coefficient equations and the cross-level interaction two-way FE models (i.e. models 5 and 6). The results and conclusions were consistent with those presented. In other analyses, we also retained the country-level controls (i.e. unemployment rate and wage coordination) in the random coefficient models and the cross-level interaction two-way FE models. The country-level controls were not significant and did not alter the coefficients for work-family policies.
} 
These models are similar to the fourth except they include an interaction between work-family policies and having children (Model 5) or being female (Model 6) $\left(\beta \mathrm{WF}_{\mathrm{jt}} * \mathrm{M}_{\mathrm{ijt}}\right)$. Following Giesselmann and Schmidt-Catran (2018), we adjust for the interaction of mother/female and the country dummies $\left(\beta \mathrm{C}_{\mathrm{j}}^{*} \mathrm{M}_{\mathrm{ijt}}\right)$ to ensure the cross-level interactions are truly within estimators. The fifth and sixth models have the same strengths as the fourth, but assess differences between mothers and childless women, and women and men.

We use the multi-level cross-sectional models to follow prior research and include a larger set of countries. Despite having fewer countries, the panel models provide a much-needed longitudinal perspective. There are likely to be stable unobserved characteristics of countries that are confounded with work-family policies and labor market outcomes. Such unobserved characteristics could introduce omitted variable bias, and may account for any significant effects of policies in the cross-sectional models. Only the panel models remove such unobserved stable cross-national and generic temporal factors. We emphasize that the six models are complementary. No one model can definitively assess the relationship between work-family policies and labor market outcomes. We focus on the cumulative evidence across models and outcomes. Each model has assumptions, strengths, and weaknesses, and robust evidence best informs conclusions about the relationships in question.

\section{Expectations}

If the tradeoff hypothesis is correct, both measures of women's earnings and managerial attainment should be negatively associated with paid leave, and at an increasing rate (i.e., negative squared term). Paid leave should be positively associated with the gaps in these outcomes between women and men and mothers and non-mothers. The literature is somewhat inconsistent in expectations about public childcare. Although Pettit and Hook argued that public 
childcare could have beneficial effects, Mandel and colleagues implied that childcare should be negatively associated with women's earnings, annual earnings, and managerial or lucrative managerial attainment, and should worsen gender gaps (see endnote 4). The literature has been ambiguous about how work-family policies influence employment, but the tradeoff hypothesis implies work-family policies should be negatively associated with full-time employment. ${ }^{16}$ Again, the squared term for paid leave allows us to test if particularly long leaves discourage women's and mothers' employment more than shorter leaves (Nieuwenhuis et al. 2017). If the tradeoff hypothesis is accurate, both paid leave and childcare should be positively associated with occupation percent female (the percent of women's in one's occupation), and worsen gaps between women and men and mothers and non-mothers.

\section{RESULTS}

The tables display the coefficients for the work-family policy variables, the mother and female variables, and, when applicable, the cross-level interaction terms. The other coefficients are available upon request. We first concentrate on the models of earnings and full-time earnings because these have arguably been the most prominent outcomes in the literature. After earnings, we report the results more concisely to avoid repetition.

\section{Annual Earnings and Full-Time Earnings}

Table 2 displays the models of annual earnings for all employees, and Appendix III displays the models for annual earnings among full-time employees. Again, the first three

\footnotetext{
${ }^{16}$ Some argue childcare encourages female employment (Pettit and Hook 2005, 2009), in part by encouraging women to return to work (Kluve and Tamm 2013; Ziefle and Gangl 2014). Others claim work-family policies undermine women's and mother's employment (Gangl and Ziefle 2015; Lalive and Zweimueller 2009; Schoenberg and Ludsteck 2014).
} 
models are cross-national multilevel models. The first models in Tables 2 and Appendix III assess if women's earnings are associated with their country's work-family policies. In the first models, paid leave, paid leave-squared and childcare coverage are all insignificant.

\section{[ TABLE 2 ABOUT HERE ]}

The second models assess whether the relationship between work-family policies and women's earnings differ between mothers and non-mothers. For both outcomes, there appears to be a nonlinear negative relationship between the length of paid leave and mothers' earnings relative to non-mothers. Paid leave is significantly negative in Appendix III (and $\mathrm{p}<.10$ in Table 2) and paid leave-squared is significantly positive (in both Table 2 and Appendix III). Relative to non-mothers, mothers' earnings decline as paid leave is longer, but this decline tapers off at about 100 weeks. These significant negative coefficients for paid leave are consistent with the tradeoff hypothesis, but the significant positive coefficients for paid leave-squared contradict it. In both tables, the statistical interaction between childcare coverage and mother status is not significant, suggesting the relationship between policies and annual earnings are similar for mothers and childless women. As well, the second models show there is no significant relationship between work-family policies and women's earnings among non-mothers (i.e. the "main effects" in the second models).

The third models assess if the relationship between work-family policies and earnings differ between women and men. In both tables, the interactions between being female and workfamily policies are not significant, implying that the policies have a similar connection to earnings for women and men.

As expected, earnings are significantly and negatively associated with the share of women in one's occupation, being a mother (in Table 2), and being female. Indeed, the most 
robust finding across all tables is that the female coefficient is almost always significant for adverse outcomes. Thus, work-family policies certainly do not explain away broader gender inequalities in labor market outcomes.

The next three models (in Table 2) use the panel of 12 countries with country and year fixed effects. The fourth models assess if women's earnings are associated with within-country temporal variation in work-family policies. In the fourth model in Table 2, work-family policies are insignificant. However, the fourth model in Appendix III shows that paid leave is significantly positive, paid-leave squared is significantly negative, and childcare coverage is significantly negatively related to full-time earnings. Turning back to Table 2, annual earnings, the coefficients for paid leave contradict the tradeoff hypothesis. However, the coefficients for paid-leave squared and childcare coverage are consistent with the hypothesis.

The fifth models assess whether the relationship between paid leave and childcare coverage and earnings differ between mothers and non-mothers. None of the cross-level interactions in Table 2 (annual earnings) or Appendix III (full-time earnings) are significant.

The sixth models assess if the relationship between work-family policies and earnings differ between women and men. For both annual earnings and full-time earnings, paid leave is significantly positively associated with women's earnings relative to men's earnings. Also, for both types of earnings, paid leave squared has a significant negative interaction with being female. This implies the positive effect of paid leave for women's earnings (relative to men's earnings) slows down at about 100 weeks for earnings and 39 weeks for full-time earnings. The significant positive coefficients for paid leave contradict the tradeoff hypothesis, while the coefficients for paid leave-squared are consistent with it. The interaction between childcare 
coverage and being female is not significant in Table 2 . However, this interaction is significantly negative in Appendix III (full-time earnings), which is consistent with the tradeoff hypothesis.

One way to distill the results for earnings in Table 2 and Appendix III is to count the coefficients that support the tradeoff hypothesis. Counting the policy coefficients in models 1, 2, 4 and 5, and the cross-level interactions in models 2, 3, 5 and 6 yields 48 relevant coefficients. Of the 48 coefficients that speak to the tradeoff hypothesis, 6 are significant and consistent with the hypothesis. By contrast, 5 coefficients are significant and contradict the tradeoff hypothesis. Moreover, 37 of the 48 coefficients are not significant. Hence, while there is some evidence for the tradeoff hypothesis, there is also evidence contradicting it, and a clear majority of the relevant coefficients is insignificant. From this, we conclude the results fail to support the hypothesis that work-family policies trigger tradeoffs for womens' and mothers' earnings.

\section{Employment and Full-Time Employment}

Table 3 and Appendix IV display logistic regression models of employment and full-time employment. We use the same approach as for earnings, but now summarize the remaining results more concisely. Again, 48 coefficients in Tables 3 and Appendix IV are relevant to the tradeoff hypothesis. The prevailing pattern for employment and full-time employment is insignificance. Specifically, 36 of the 48 relevant coefficients are not statistically significant.

\section{[ TABLE 3 ABOUT HERE ]}

Zero coefficients for employment in Table 3 support the tradeoff hypothesis. Six coefficients for full-time employment in Appendix IV are significant and consistent with the tradeoff hypothesis. For example, paid leave is associated with significantly lower earnings for mothers relative to non-mothers (models 2 and 5). However, one coefficient in Table 3 and five coefficients in Appendix IV are significant and contradict the tradeoff hypothesis. For example, 
childcare coverage is significantly positively associated with mothers' earnings relative to nonmothers (model 2) and female earnings relative to men's (model 6).

\section{Being a Manager or a Lucrative Manager}

Table 4 presents models of being a manager while Appendix V displays models of being a lucrative manager. A clear majority of the relevant coefficients, 36 of 48, are insignificant. Also, similar shares of coefficients both support and contradict the tradeoff hypothesis.

\section{[ TABLE 4 ABOUT HERE ]}

Of the 48 relevant coefficients in Table 4 and Appendix V, only 5 are significant and consistent with the tradeoff hypothesis. Paid leave is significantly negative in models $4-5$ of Table 4, and model 1 of Appendix V. In addition, the interaction between female and childcare coverage is significantly negative in both models 6 .

By contrast, 7 coefficients are significant and contradict the tradeoff hypothesis. Paid leave squared is significantly positive in models $4-5$ of Table 4 , and models 1, 2 and 4 of Appendix V. Also, childcare coverage is significantly positive in models 4 and 5 of Table 4 .

\section{Occupation Percent Female}

Table 5 examines the occupation percent female outcome (the percent of women's in one's occupation). Consistent with past research, this variable is negatively associated with annual earnings and annual full-time earnings (see Table 2 and Appendix III). Thus, if workfamily policies are positively associated with the occupation percent female, this would indirectly trigger tradeoffs. Of the 24 coefficients relevant to the tradeoff hypothesis, 17 are insignificant. Again, the prevailing pattern is a lack of significance. Unlike the other Tables, a significant positive coefficient is consistent with the tradeoff hypothesis.

[ TABLE 5 ABOUT HERE ] 
Of the 24 relevant coefficients, four are significantly positive. Childcare coverage is significantly positive in models 1 and 2, and paid leave is significantly positive in model 4 . Also, paid leave has a significant positive interaction with being a mother in model 5 .

However, contradicting the tradeoff hypothesis, three key coefficients are significantly negative. Paid leave squared and childcare coverage are significantly negative in models 4 . Also, paid leave-squared has a significant negative interaction with being a mother in model 5 .

\section{DISCUSSION}

Motivated by the prominent and influential paradox/tradeoffs literature, this study provides a comprehensive new analysis of the relationship between work-family policies and labor market outcomes. We analyze two work-family policies and seven labor market outcomes. With samples of working-aged women, mothers and childless women, and women and men, we estimate multi-level models of a cross-section of 21 rich democracies in the mid-2000s and twoway fixed effects models of a panel of 12 rich democracies across recent decades.

Overall, the analyses undermine claims that work-family reconciliation policies have adverse labor market consequences for women. The prevailing pattern, and our primary conclusion, is that work-family policies are not associated with labor market outcomes for women or mothers. The vast majority of coefficients for work-family policies fail to reject the null hypothesis of no effects. Across all seven labor market outcomes, including main effects and squared terms, and cross-level interactions, 168 coefficients can be used to evaluate the tradeoff hypothesis. To be clear, those 168 coefficients do not include the main effects of policies in samples with both men and women (i.e. models 3 and 6). Of those 168 coefficients, the vast majority (126) of relevant coefficients are insignificant. Indeed, only 21 are statistically 
significant and consistent with the hypothesis and 21 of the relevant coefficients are statistically significant and contradict the hypothesis. Thus, there is about as much evidence contradicting the tradeoff hypothesis as supporting it and the prevailing pattern is insignificance.

Given that we present a large quantity of results, readers may be legitimately concerned that only certain models can provide the correct test of the tradeoff hypothesis. With the aim of being judicious, we now assess the evidence under seven different conditions.

First, perhaps paid leave and its square should be treated as a pair and support for the tradeoff hypothesis could be found if either paid leave or its square is significant and consistent. Using this standard, only 13 of the 112 relevant coefficients are significant and support the hypothesis while 4 significantly contradict the tradeoff hypothesis. Second, one could disregard the analyses of employment as some have argued that work-family policies increase women's employment. Focusing on the other six outcomes, 15 of 144 relevant coefficients are significant and consistent with the tradeoff hypothesis and 15 significantly contradict the hypothesis. Third, some might argue that paid leave is most likely to trigger tradeoffs, and the literature is ambivalent about whether public childcare is harmful (even though Mandel and Semyonov argue both policies have the same effects, see endnote 4). Focusing solely on paid leave and ignoring the childcare coefficients, only 13 of 112 coefficients are significant and consistent with the tradeoff hypothesis while 16 significantly contradict the hypothesis.

Fourth, one could concentrate solely on the cross-sectional models that are similar to prior research. In these, only 5 of 84 coefficients are significant and consistent with the tradeoff hypothesis while 7 significantly contradict the hypothesis. Fifth, one could focus solely on the panel models given they advantageously remove stable differences between countries and generic changes over time. In these models, 16 of 84 coefficients are significant and consistent 
with the tradeoff hypothesis while 14 significantly contradict the hypothesis. Finally, prior research often presented the cross-level interactions as the key tests. In most models, the crosslevel interactions are not significant. Of the 84 cross-level interactions, only 9 are significant and consistent with the hypothesis. By contrast, 8 significantly contradict the tradeoff hypothesis.

Therefore, overall and under multiple conditions, the prevailing pattern is that workfamily policies are not significantly associated with women's and mothers' labor market outcomes. We find about as much evidence that work-family policies alleviate gender and motherhood inequalities as worsen those inequalities. ${ }^{17}$ Hence, we conclude that work-family reconciliation policies do not trigger tradeoffs and paradoxes in terms of gender equality with adverse labor market consequences for women.

The pattern of insignificance certainly suggests greater caution for researchers claiming that work-family policies trigger paradoxes and tradeoffs. Yet because these questions remain policy-relevant and theoretically salient, we propose several directions for future research.

First, while the cross-national tradeoff literature has largely been cross-sectional, an emerging literature has used longitudinal approaches in single country case studies. Our study is one small step toward combining the strengths of the cross-national and longitudinal studies. Therefore, we encourage pooling multiple waves of data from multiple countries. Second, at least some research has been unclear about the precise methods and data utilized (e.g. see endnotes 6-7). To avoid this problem, Appendix VI includes our principal code, which should enable replication. Third, there is a growing literature on fatherhood labor market premia and

${ }^{17}$ Because our analyses feature a large number and wide variety of tests, it is even possible that any significant results are due to statistical chance or multiple testing biases as much as any real relationship. This provides an even stronger case that the correct conclusion is that there is not a significant relationship between the policies and labor market outcomes. 
motherhood penalties (Abendroth et al. 2014; Aisenbrey et al. 2009; Budig et al. 2012; Misra et al. 2011; Petersen et al. 2014). We do not compare mothers and fathers, but instead focus on mothers and non-mothers given one primary aim of work-family policies was to facilitate women's employment following childbirth. Beyond sex differences, future research could productively focus on exploring the outcomes for parents of both sexes.

Fourth, considerable progress has been made in understanding how firms and organizations influence gender inequalities in the labor market (Stainback et al. 2010). In the process, scholars have shown firms play a crucial mediating role, as work-family policies are reflected through firm characteristics and practices (Kelly 2010; Kmec and Skaggs 2014). Plausibly, the implementation and consequences of country-level work-family policies vary across organizations, and organizational heterogeneities could partially explain the lack of robust results (Mun and Jung 2018). Hence, much could be learned with a three-level data structure of individuals nested within firms within countries. Fifth, others have explored how work-family policy tradeoffs differ across groups (Hook 2015; Korpi et al. 2013; Mandel 2012; Mandel and Shalev 2009; Keck and Saraceno 2013). That is, work-family policies could provide differing effects for highly-educated/highly-skilled women versus less-educated/less-skilled women or for women of child-bearing versus child-rearing or later ages. That said, although Mandel and colleagues highlight the intersections with social class, they express little doubt that work-family policies lead to paradoxes for all women (regardless of class). Nevertheless, future research can use our research design to better examine how work-family policies are potentially differently associated with outcomes for different groups of women.

In the past 10-15 years, pioneering research has inspired a lively debate about the potentially inegalitarian consequences of generous work-family policies. By raising critical 
questions and utilizing innovative cross-national and multi-level research designs, their work has encouraged valuable research and discussion. Nevertheless, after conducting a comprehensive analysis, we ultimately conclude that work-family policies do not trigger gendered paradoxes and tradeoffs. As a result of these findings, researchers should proceed with greater caution, both methodologically and in terms of policy. That said, it certainly remains worthwhile to analyze the consequences of work-family policies given their salience in the policy debates of countries and in the growing presence of women and mothers in the paid labor force. 


\section{REFERENCES}

Abendroth, Anja-Kristin, Matt L. Huffman, and Judith Treas. 2014. "The Parity Penalty in Life Course Perspective: Motherhood and Occupational Status in 13 European Countries." American Sociological Review 79: 993-1014.

Aisenbrey, Silke, Marie Evertsson, and Daniela Grunow. 2009. "Is There a Career Penalty for Mothers' Time Out? A Comparison of Germany, Sweden and the United States." Social Forces 88: 573-606.

Albrecht, James, Anders Bjorklund, and Susan Vroman. 2003. "Is There a Glass Ceiling in Sweden?" Journal of Labor Economics 21: 145-177.

Baker, Michael, Jonathan Gruber, and Kevin Milligan. 2008. "Universal Child Care, Maternal Labor Supply, and Family Well-Being.” Journal of Political Economy 116: 709-745.

Bauernschuster, Stefan and Martin Schlotter. 2015. "Public Child Care and Mothers' Labor Supply - Evidence from Two Quasi-Experiments”. Journal of Public Economics 123: 116.

Bergmann, Barbara R. 2009. "Long Leaves, Child Well-Being, and Gender Inequality.” Pp. 6777 in Gender Equality, edited by J. Gornick and M.K. Meyers. New York: Verso.

Blome, Agnes. 2017. The Politics of Work-Family Policies in Germany and Italy New York: Routledge.

Boeckmann, Irene, Michelle Budig and Joya Misra. 2012. The Work-Family Policy Indicators. Sociology Department, University of Massachusetts-Amherst. doi: 10.7275/R5WD3XHS.

Boeckmann, Irene, Joya Misra, and Michelle J. Budig. 2015. "Cultural and Institutional Factors Shaping Mothers' Employment and Working Hours in Postindustrial Countries.” Social Forces 93: 1301-1333.

Brady, David, Evelyne Huber and John D. Stephens. 2014. Comparative Welfare States Data Set. WZB Berlin Social Science Center and University of North Carolina.

Bryan, Mark L. and Stephen P. Jenkins. 2016. "Multilevel Modeling of Country Effects: A Cautionary Tale.” European Sociological Review 32: 3-22.

Budig, Michelle J., Joya Misra, and Irene Boeckmann. 2012. "The Motherhood Penalty in CrossNational Perspective: The Importance of Work-Family Policies and Cultural Attitudes." Social Politics 19: 163-193.

Cascio, Elizabeth U. 2009. "Maternal Labor Supply and the Introduction of Kindergartens into American Public Schools," The Journal of Human Resources 44: 140-170.

Charles, Maria and David B. Grusky. 2004. Occupational Ghettos Stanford, CA: Stanford University Press.

Cooke, Lynn Prince and Janeen Baxter. 2010. "'Families' in International Context: Comparing Institutional Effects Across Western Societies.” Journal of Marriage and Family 72: 516536.

Dahl, Gordon B., Katrine V. Løken, Magne Mogstad and Kari Vea Salvanes. 2016. "What is the Case for Paid Maternity Leave?" Review of Economics and Statistics 98: 655-670.

Dieckhoff, Martina, Vanessa Gash and Nadia Steiber. 2015. "Measuring the Effect of Institutional Change on Gender Inequality in the Labour Market." Research in Social Stratification and Mobility 39: 59-75.

Evertsson, Marie and Ann-Zofie Duvander. 2010. "Parental Leave - Possibility or Trap? Family Leave Length Effect Swedish Women's Labor Market Opportunities.” European Sociological Review 27: 435-450. 
Ferrarini, Tommy. 2006. Families, States and Labour Markets Cheltenham: Edward Elgar.

Gangl, Markus and Andrea Ziefle. 2015. "The Making of a Good Woman: Extended Parental Leave Entitlements and Mothers' Work Commitment in Germany." American Journal of Sociology 121: 511-563.

Gasser, Martin and Lena Liechti. 2015. "Gender Equality Trade-offs Re-examined: Evidence from Swiss Cantons.” Community, Work \& Family 18: 249-267.

Gauthier, Anne H. 2010. Comparative Family Policy Database, Version 3. http://www.demogr.mpg.de/cgi-bin/databases/FamPolDB/index.plx.

Giesselmann, Marco and Alexander Schmidt-Catran. 2018. "Getting the Within Estimator of Cross-Level Interactions in Multilevel Models with Pooled Cross-Sections: Why Country Dummies (Sometimes) Do Not Do the Job." Sociological Methodology Forthcoming.

Gornick, Janet C. and Marcia K. Meyers. 2008. "Creating Gender Egalitarian Societies: An Agenda for Reform." Politics \& Society 36: 313-349. 2003a. The Family Policy Database (2). http://www.lisdatacenter.org/resources/otherdatabases/ . 2003b. Families That Work New York: Russell Sage Foundation.

Gornick, Janet C., Marcia K. Meyers and Katherin E. Ross. 1998. "Public Policies and the Employment of Mothers: A Cross-National Study." Social Science Quarterly 79: 35-54. 1997. "Supporting the Employment of Mothers: Policy Variation Across Fourteen Welfare States." Journal of European Social Policy 7: 45-70.

Goux, Dominique and Eric Maurin. 2010. "Public School Availability for Two-Year Olds and Mothers' Labour Supply.” Labour Economics 17: 951-962.

Havnes, Tarjei, and Magne Mogstad. "Money for Nothing? Universal Child Care and Maternal Employment." Journal of Public Economics 95: 1455-1465.

Hook, Jennifer L. 2010. "Gender Inequality in the Welfare State: Sex Segregation in Housework, 1965-2003." American Journal of Sociology 115: 1480-1523. . 2015. "Incorporating 'Class' Into Work-Family Arrangements: Insights From and For Three Worlds." Journal of European Social Policy 25: 14-32.

Keck, Wolfgang and Chiara Saraceno. 2013. "The Impact of Different Social-Policy Frameworks on Social Inequalities among Women in the European Union: The LabourMarket Participation of Mothers." Social Politics 20: 297-328.

Kelly, Erin. 2010. "Failure to Update: An Institutional Perspective on Noncompliance with the Family and Medical Leave Act." Law \& Society Review 44:33-66.

Kluve, Jochen and Marcus Tamm. 2013. "Parental Leave Regulations, Mothers' Labor Force Attachment and Fathers' Childcare Involvement: Evidence from a Natural Experiment." Journal of Population Economics 26: 983-1005.

Kmec, Julie A. and Sheryl Skaggs. 2014. "The 'State' of Equal Employment Opportunity Law and Managerial Gender Diversity." Social Problems 61: 530-558.

Korpi, Walter. 2000. "Faces of Inequality: Gender, Class and Patterns of Inequalities in Different Types of Welfare States." Social Politics 7: 127-191.

Korpi, Walter, Tommy Ferrarini and Stefan Englund. 2013. "Women's Opportunities Under Different Family Policy Constellations: Gender, Class, and Inequality Tradeoffs in Western Countries Re-Examined." Social Politics 20: 1-40.

Lalive, Rafael and Josef Zweimueller. 2009. "How Does Parental Leave Affect Fertility and Return to Work? Evidence from Two Natural Experiments." Quarterly Journal of Economics 124: 1363-1402. 
Luxembourg Income Study (LIS) Database, http://www.lisdatacenter.org (U.S.; September 2013September 2014). Luxembourg: LIS.

Mandel, Hadas. 2012. "Winners and Losers: The Consequences of Welfare State Policies for Gender Wage Inequality." European Sociological Review 28: 241-262.

Mandel, Hadas and Moshe Semyonov. 2006. "A Welfare State Paradox: State Interventions and Women's Employment Opportunities in 22 Countries." American Journal of Sociology 111: 1910-1949. 2005. "Family Policies, Wage Structures, and Gender Gaps: Sources of Earnings Inequality in 20 Countries." American Sociological Review 70: 949-967.

Mandel, Hadas and Michael Shalev. 2009. "How Welfare States Shape the Gender Pay Gap: A Theoretical and Comparative Analysis." Social Forces 87: 1873-1911.

McDonald, Peter. 2013. "Societal Foundations for Explaining Low Fertility: Gender Equity." Demographic Research 28: 981-994.

McDonald, Peter. 2006. "Low Fertility and the State: The Efficacy of Policy." Population and Development Review 32: 485-510.

Misra, Joya, Michelle J. Budig, and Irene Boeckmann. 2011. "Cross-National Patterns in Individual and Household Employment and Work Hours by Gender and Parenthood." Comparing European Workers Part A, Research in the Sociology of Work 22: 169 - 207.

Misra, Joya, Stephanie Moller and Michelle J. Budig. 2007. "Work-Family Policies and Poverty for Partnered and Single Women in Europe and North America." Gender and Society 21: 804-827.

Morgan, Kimberly J. 2006. Working Mothers and the Welfare State Stanford, CA: Stanford University Press.

Morgan, Kimberly J. and Kathrin Zippel. 2003. "Paid to Care: The Origins and Effects of Care Leave Policies in Western Europe." Social Politics 3: 49-85.

Multilinks (2011). Multilinks Database on Intergenerational Policy Indicators. Version 2.1, Multilinks Project and Wissenschaftszentrum Berlin fuer Sozialforschung (WZB), http://multilinks-database.wzb.eu (date 20 May 2017).

Mun, Eunmi and Jiwook Jung. 2018. "Policy Generosity, Employer Heterogeneity, and Women's Employment Opportunities: The Welfare State Paradox Reexamined." American Sociological Review 83: 508-535.

Nieuwenhuis, Rense. 2014. Family policy outcomes: Combining institutional and demographic explanations of women's employment and earnings inequality in OECD countries, 19752005 (SSRN Scholarly Paper No. ID 2438617). Social Science Research Network, Rochester, NY.

Nieuwenhuis, Rense, Ariana Need, and Henk Van der Kolk. 2017. "Is There Such a Thing as Too Long Childcare Leave?” International Journal of Sociology and Social Policy 37: 215.

Peterson, Trond, Andrew M. Penner, and Geir Høgnes. 2014. "From Motherhood Penalties to Husband Premia: The New Challenge for Gender Equality and Family Policy, Lessons From Norway." American Journal of Sociology 119: 1434-1472. . 2010. "The Within-Job Motherhood Wage Penalty in Norway, 1979-1996." Journal of Marriage and Family 72: 1274-1288.

Pettit, Becky and Jennifer L. Hook. 2009. Gendered Tradeoffs. New York: Russell Sage Foundation. 
. 2005. "The Structure of Women's Employment in Comparative Perspective." Social Forces 84: 779-801.

Ray, Rebecca, Janet C. Gornick, and John Schmitt. 2010. "Who Cares? Assessing Generosity and Gender Equality in Parental Leave Policy Designs in 21 Countries." Journal of European Social Policy 20: 196-216.

Schober, Pia S. 2014. "Parental Leaves and Domestic Work of Mothers and Fathers: A Longitudinal Study of Two Reforms in West Germany." Journal of Social Policy 43: 351-372.

Schoenberg, Uta, and Johannes Ludsteck. 2014. "Expansions in Maternity Leave Coverage and Mothers' Labor Market Outcomes After Childbirth.” Journal of Labor Economics 32: 469-505.

Stainback, Kevin, Donald Tomaskovic-Devey, and Sheryl Skaggs. 2010. "Organizational Approaches to Inequality: Inertia, Relative Power, and Environments.” Annual Review of Sociology 36: 225-247.

Stegmueller, Daniel. 2013. "How Many Countries for Multilevel Modeling? A Comparison of Frequentist and Bayesian Approaches." American Journal of Political Science 57: 748761.

Steiber, Nadia and Barbara Haas. 2012. "State of the Art. Advances in Explaining Women's Employment Patterns." Socio-Economic Review 10: 343-367.

Thévenon, Olivier and Anne Solaz 2015. "Labor Market Consequences of Parental Leave Policies in OECD Countries." Paper presented at Population Association of America Meetings.

Waldfogel, Jane. 1998. "The Family Gap for Young Women in the United States and Britain: Can Maternity Leave Make a Difference?" Journal of Labor Economics 16: 505-545.

Ziefle, Andrea and Markus Gangl. 2014. "Do Women Respond to Changes in Family Policy? A Quasi-Experimental Study of the Duration of Mothers' Employment Interruptions in Germany." European Sociological Review 30: 562-581. 
Table 1. Work-Family Policy Variables for Each Country-Year in the Sample.

\section{Weeks of Paid Leave Publicly Subsidized Childcare Coverage}

(0-3 Year Olds)

\begin{tabular}{lcc}
\hline Austria 1994 & 104 & 4.3 \\
Austria 2004 & 104 & 9.2 \\
Belgium 2000 & 21 & 36 \\
Canada 1987 & 15 & 3.8 \\
Canada 2004 & 50 & 26.9 \\
Czech Republic 2004 & 156 & 8 \\
Denmark 1987 & 24 & 47.2 \\
Denmark 2004 & 46 & 57.1 \\
Estonia 2004 & 156 & 22 \\
Finland 1987 & 156 & 20 \\
Finland 2004 & 156 & 25 \\
France 1984 & 0 & 20 \\
France 2005 & 156 & 42 \\
Germany 1984 & 26 & 1.6 \\
Germany 2007 & 52 & 15.3 \\
Greece 2004 & 0 & 7 \\
Hungary 2005 & 156 & 6 \\
Ireland 1994 & 10 & 2 \\
Ireland 2007 & 24 & 24 \\
Israel 1986 & 6 & $44.4^{\mathrm{a}}$ \\
Israel 2005 & 6 & $20.5^{\mathrm{a}}$ \\
Luxembourg 1985 & 8 & 1 \\
Luxembourg 2004 & 34 & 2.8 \\
Netherlands 1990 & 6 & 2 \\
Netherlands 2004 & 10 & 14.5 \\
Slovenia 2004 & 48 & 27 \\
South Korea 2006 & 59 & 37.7 \\
Spain 1990 & 10 & 3.3 \\
Spain 2004 & 10 & 15.1 \\
Sweden 1995 & 61 & 37 \\
UK 2004 & 26 & 26 \\
USA 1986 & 0 & 1 \\
USA 2004 & 0 & 6 \\
& &
\end{tabular}

a. The childcare coverage rates for Israel only apply to two-year olds. We re-estimated all models without Israel and found similar results. 
Table 2. Multilevel Linear Regression Models of Annual Earnings of Employees Aged 25-54:

Coefficients and (Z- or T-scores).

\begin{tabular}{|c|c|c|c|c|c|c|}
\hline & $\begin{array}{c}\text { M1: } \\
\text { Female } \\
\text { Cross- } \\
\text { Section }\end{array}$ & $\begin{array}{c}\text { M2: } \\
\text { Female } \\
\text { Cross- } \\
\text { Section }\end{array}$ & $\begin{array}{c}\text { M3: Female } \\
\text { \& Male } \\
\text { Cross- } \\
\text { Section }\end{array}$ & $\begin{array}{c}\text { M4: } \\
\text { Female } \\
\text { Panel }\end{array}$ & $\begin{array}{c}\text { M5: } \\
\text { Female } \\
\text { Panel }\end{array}$ & $\begin{array}{c}\text { M6: } \\
\text { Female \& } \\
\text { Male Panel }\end{array}$ \\
\hline Paid Leave & $\begin{array}{c}.00004 \\
(.06)\end{array}$ & $\begin{array}{l}.001 \\
(1.12)\end{array}$ & $\begin{array}{c}-.0003 \\
(-.46)\end{array}$ & $\begin{array}{l}.003 \\
(.97)\end{array}$ & $\begin{array}{l}.003 \\
(.88)\end{array}$ & $\begin{array}{l}-.001 \\
(-.73)\end{array}$ \\
\hline Paid Leave $^{2}$ & $\begin{array}{c}.000001 \\
(.18)\end{array}$ & $\begin{array}{c}-.000003 \\
(-.81)\end{array}$ & $\begin{array}{c}.000001 \\
(.48)\end{array}$ & $\begin{array}{l}-.003 \\
(-1.20)\end{array}$ & $\begin{array}{c}-.00002 \\
(-.81)\end{array}$ & $\begin{array}{l}.00001 \\
(.79)\end{array}$ \\
\hline Childcare Coverage & $\begin{array}{l}.0002 \\
(.28)\end{array}$ & $\begin{array}{l}-.001 \\
(-1.02)\end{array}$ & $\begin{array}{l}-.0003 \\
(-.62)\end{array}$ & $\begin{array}{l}-.00002 \\
(-1.06)\end{array}$ & $\begin{array}{l}-.003 \\
(-1.79)\end{array}$ & $\begin{array}{c}-.0002 \\
(-.22)\end{array}$ \\
\hline $\begin{array}{l}\text { \% Women in } \\
\text { Occupation }\end{array}$ & $\begin{array}{l}-.126^{* *} \\
(-30.39)\end{array}$ & $\begin{array}{l}-.122 * * \\
(-29.51)\end{array}$ & $\begin{array}{l}-.049^{* *} \\
(-19.38)\end{array}$ & $\begin{array}{l}-.050 \\
(-2.07)\end{array}$ & $\begin{array}{l}-.047 \\
(-1.97)\end{array}$ & $\begin{array}{l}.008 \\
(.94)\end{array}$ \\
\hline Mother & & $\begin{array}{l}-.047 * * \\
(-2.12)\end{array}$ & & & $\begin{array}{l}-.054 * * \\
(-8.97)\end{array}$ & \\
\hline $\begin{array}{l}\text { Mother *Paid } \\
\text { Leave }\end{array}$ & & $\begin{array}{l}-.002 \\
(-1.95)\end{array}$ & & & $\begin{array}{r}-.001 \\
(.82)\end{array}$ & \\
\hline $\begin{array}{l}\text { Mother *Paid } \\
\text { Leave }^{2}\end{array}$ & & $\begin{array}{c}.00001 * \\
(1.98)\end{array}$ & & & $\begin{array}{l}.00001 \\
(-1.92)\end{array}$ & \\
\hline $\begin{array}{l}\text { Mother *Childcare } \\
\text { Coverage }\end{array}$ & & $\begin{array}{l}.001 \\
(1.54)\end{array}$ & & & $\begin{array}{l}.001 \\
(.61)\end{array}$ & \\
\hline Female & & & $\begin{array}{l}-.200^{* *} \\
(-7.89)\end{array}$ & & & $\begin{array}{l}-.162 * * \\
(-33.09)\end{array}$ \\
\hline Female*Paid Leave & & & $\begin{array}{l}.0001 \\
(.15)\end{array}$ & & & $\begin{array}{l}.004 * * \\
(5.03)\end{array}$ \\
\hline $\begin{array}{l}\text { Female *Paid } \\
\text { Leave }^{2}\end{array}$ & & & $\begin{array}{c}.0000003 \\
(.06)\end{array}$ & & & $\begin{array}{c}-.00002 * * \\
(-5.72)\end{array}$ \\
\hline $\begin{array}{l}\text { Female*Childcare } \\
\text { Coverage }\end{array}$ & & & $\begin{array}{l}.0002 \\
(.32)\end{array}$ & & & $\begin{array}{l}-.001 \\
(-1.02)\end{array}$ \\
\hline $\begin{array}{l}\mathrm{N} \\
\text { \# Countries }\end{array}$ & $\begin{array}{c}134,839 \\
21\end{array}$ & $\begin{array}{c}134,839 \\
21\end{array}$ & $\begin{array}{c}285,308 \\
21\end{array}$ & $\begin{array}{c}137,801 \\
12\end{array}$ & $\begin{array}{c}137,801 \\
12\end{array}$ & $\begin{array}{c}302,284 \\
12\end{array}$ \\
\hline
\end{tabular}

Notes: All models control for education, marital status, age and age-squared, number of children (except models 2 and 5), child under 5, and employment of other household member. Models 1 and 4 control for country-level unemployment rate and wage coordination. Panel models include fixed effects for countries and decades, and interactions between country fixed effects and children or female.

$* \mathrm{p}<.05, * * \mathrm{p}<.01$ 
Table 3. Multilevel Logistic Regression Models of Employment of People Aged 25-54: Coefficients and (Z-scores).

\begin{tabular}{|c|c|c|c|c|c|c|}
\hline & $\begin{array}{c}\text { M1: } \\
\text { Female } \\
\text { Cross- } \\
\text { Section }\end{array}$ & $\begin{array}{c}\text { M2: } \\
\text { Female } \\
\text { Cross- } \\
\text { Section }\end{array}$ & $\begin{array}{c}\text { M3: } \\
\text { Female } \\
\text { \& Male } \\
\text { Cross- } \\
\text { Section }\end{array}$ & $\begin{array}{c}\text { M4: } \\
\text { Female } \\
\text { Panel }\end{array}$ & $\begin{array}{c}\text { M5: } \\
\text { Female } \\
\text { Panel }\end{array}$ & $\begin{array}{c}\text { M6: } \\
\text { Female \& } \\
\text { Male Panel }\end{array}$ \\
\hline Paid leave & $\begin{array}{l}.008 \\
(1.22)\end{array}$ & $\begin{array}{l}.011^{*} \\
(2.06)\end{array}$ & $\begin{array}{l}.002 \\
(.34)\end{array}$ & $\begin{array}{l}.036 \\
(.95)\end{array}$ & $\begin{array}{l}.028 \\
(.87)\end{array}$ & $\begin{array}{l}.017 \\
(.61)\end{array}$ \\
\hline Paid leave $^{2}$ & $\begin{array}{l}-.00004 \\
(-.94)\end{array}$ & $\begin{array}{l}-.00005 \\
(-1.55)\end{array}$ & $\begin{array}{c}-.00001 \\
(-.39)\end{array}$ & $\begin{array}{l}-.0002 \\
(-1.02)\end{array}$ & $\begin{array}{l}-.0002 \\
(-.91)\end{array}$ & $\begin{array}{c}-.0001 \\
(-.85)\end{array}$ \\
\hline Childcare Coverage & $\begin{array}{l}.006 \\
(.96)\end{array}$ & $\begin{array}{l}.0003 \\
(.05)\end{array}$ & $\begin{array}{l}-.006 \\
(-1.00)\end{array}$ & $\begin{array}{l}-.008 \\
(-.27)\end{array}$ & $\begin{array}{l}-.008 \\
(-.43)\end{array}$ & $\begin{array}{l}-.009 \\
(-.43)\end{array}$ \\
\hline Mother & & $\begin{array}{l}-.160 \\
(-.88)\end{array}$ & & & $\begin{array}{l}-.193 * \\
(-2.34)\end{array}$ & \\
\hline Mother*Paid Leave & & $\begin{array}{l}-.006 \\
(-.94)\end{array}$ & & & $\begin{array}{l}.0001 \\
(1.32)\end{array}$ & \\
\hline $\begin{array}{l}\text { Mother *Paid } \\
\text { Leave }^{2}\end{array}$ & & $\begin{array}{l}.00003 \\
(.68)\end{array}$ & & & $\begin{array}{l}-.0001 \\
(-1.53)\end{array}$ & \\
\hline $\begin{array}{l}\text { Mother*Childcare } \\
\text { Coverage }\end{array}$ & & $\begin{array}{c}.009 \\
(1.37)\end{array}$ & & & $\begin{array}{l}.001 \\
(.11)\end{array}$ & \\
\hline Female & & & $\begin{array}{c}-1.552 * * \\
(-7.72)\end{array}$ & & & $\begin{array}{c}-1.107 * * \\
(-9.10)\end{array}$ \\
\hline Female*Paid Leave & & & $\begin{array}{l}.005 \\
(.76)\end{array}$ & & & $\begin{array}{l}.018 \\
(1.11)\end{array}$ \\
\hline $\begin{array}{l}\text { Female *Paid } \\
\text { Leave }^{2}\end{array}$ & & & $\begin{array}{c}-.00002 \\
(-.41)\end{array}$ & & & $\begin{array}{c}-.0001 \\
(-.87)\end{array}$ \\
\hline $\begin{array}{l}\text { Female*Childcare } \\
\text { Coverage }\end{array}$ & & & $\begin{array}{l}.012 \\
(1.71)\end{array}$ & & & $\begin{array}{l}.013 \\
(.59)\end{array}$ \\
\hline $\begin{array}{l}\mathrm{N} \\
\text { \# Countries }\end{array}$ & $\begin{array}{c}181,995 \\
21\end{array}$ & $\begin{array}{c}181,995 \\
21\end{array}$ & $\begin{array}{c}354,027 \\
21\end{array}$ & $\begin{array}{c}195,193 \\
12\end{array}$ & $\begin{array}{c}195,193 \\
12\end{array}$ & $\begin{array}{c}382,416 \\
12\end{array}$ \\
\hline
\end{tabular}

Notes: All models control for education, marital status, age and age-squared, number of children (except models 2 and 5), child under 5, and employment of other household member. Models 1 and 4 control for country-level unemployment rate and wage coordination. Panel models include fixed effects for countries and decades, and interactions between country fixed effects and children or female.

$* \mathrm{p}<.05, * * \mathrm{p}<.01$ 
Table 4. Multilevel Logistic Regression Models of Being a Manager Among Employees Aged 25-54: Coefficients and (Z-scores).

\begin{tabular}{|c|c|c|c|c|c|c|}
\hline & $\begin{array}{c}\text { M1: } \\
\text { Female } \\
\text { Cross- } \\
\text { Section }\end{array}$ & $\begin{array}{c}\text { M2: } \\
\text { Female } \\
\text { Cross- } \\
\text { Section }\end{array}$ & $\begin{array}{c}\text { M3: Female } \\
\text { \& Male } \\
\text { Cross- } \\
\text { Section }\end{array}$ & $\begin{array}{c}\text { M4: } \\
\text { Female } \\
\text { Panel }\end{array}$ & $\begin{array}{c}\text { M5: } \\
\text { Female } \\
\text { Panel }\end{array}$ & $\begin{array}{c}\text { M6: } \\
\text { Female \& } \\
\text { Male } \\
\text { Panel }\end{array}$ \\
\hline Paid leave & $\begin{array}{l}-.019 \\
(-1.51)\end{array}$ & $\begin{array}{c}-.018 \\
(-1.46)\end{array}$ & $\begin{array}{c}-.016 \\
(-1.74)\end{array}$ & $\begin{array}{l}-.120^{* *} \\
(-6.16)\end{array}$ & $\begin{array}{l}-.088^{* *} \\
(-4.64)\end{array}$ & $\begin{array}{c}-.093 * * \\
(-3.36)\end{array}$ \\
\hline Paid leave $^{2}$ & $\begin{array}{l}.0001 \\
(1.66)\end{array}$ & $\begin{array}{l}.0001 \\
(1.66)\end{array}$ & $\begin{array}{l}.0001 \\
(1.94)\end{array}$ & $\begin{array}{c}.0007 * * \\
(6.58)\end{array}$ & $\begin{array}{c}.0005^{* *} \\
(4.94)\end{array}$ & $\begin{array}{c}.0005^{* *} \\
(3.49)\end{array}$ \\
\hline Childcare Coverage & $\begin{array}{l}-.016 \\
(-1.42)\end{array}$ & $\begin{array}{c}-.017 \\
(-1.43)\end{array}$ & $\begin{array}{l}-.006 \\
(-.71)\end{array}$ & $\begin{array}{l}.088 * * \\
(4.36)\end{array}$ & $\begin{array}{l}.040 * * \\
(2.66)\end{array}$ & $\begin{array}{l}.060 * * \\
(3.29)\end{array}$ \\
\hline Mother & & $\begin{array}{l}-.114 \\
(-1.29)\end{array}$ & & & $\begin{array}{c}-.208 * * \\
(-2.96)\end{array}$ & \\
\hline $\begin{array}{l}\text { Mother *Paid } \\
\text { Leave }\end{array}$ & & $\begin{array}{l}-.004 \\
(-.97)\end{array}$ & & & $\begin{array}{c}.013 \\
(1.29)\end{array}$ & \\
\hline $\begin{array}{l}\text { Mother *Paid } \\
\text { Leave }^{2}\end{array}$ & & $\begin{array}{l}.00002 \\
(1.05)\end{array}$ & & & $\begin{array}{l}-.0001 \\
(-1.66)\end{array}$ & \\
\hline $\begin{array}{l}\text { Mother *Childcare } \\
\text { Coverage }\end{array}$ & & $\begin{array}{l}-.002 \\
(-.50)\end{array}$ & & & $\begin{array}{l}.008 \\
(.80)\end{array}$ & \\
\hline Female & & & $\begin{array}{r}-.485^{* *} \\
(-2.81)\end{array}$ & & & $\begin{array}{c}-.155 \\
(-1.88)\end{array}$ \\
\hline Female*Paid Leave & & & $\begin{array}{l}-.003 \\
(-.51)\end{array}$ & & & $\begin{array}{l}.020 \\
(1.64)\end{array}$ \\
\hline $\begin{array}{l}\text { Female *Paid } \\
\text { Leave }^{2}\end{array}$ & & & $\begin{array}{l}.00002 \\
(.58)\end{array}$ & & & $\begin{array}{l}-.0001 \\
(-1.58)\end{array}$ \\
\hline $\begin{array}{l}\text { Female*Childcare } \\
\text { Coverage }\end{array}$ & & & $\begin{array}{l}-.011 \\
(-1.84)\end{array}$ & & & $\begin{array}{l}-.028^{*} \\
(-2.01)\end{array}$ \\
\hline $\begin{array}{l}\mathrm{N} \\
\text { \# Countries }\end{array}$ & $\begin{array}{c}134,839 \\
21\end{array}$ & $\begin{array}{c}134,839 \\
21\end{array}$ & $\begin{array}{c}285,308 \\
21\end{array}$ & $\begin{array}{c}137,801 \\
12\end{array}$ & $\begin{array}{c}137,801 \\
12\end{array}$ & $\begin{array}{c}302,284 \\
12\end{array}$ \\
\hline
\end{tabular}

Notes: All models control for education, marital status, age and age-squared, number of children (except models 2 and 5), child under 5, and employment of other household member. Models 1 and 4 control for country-level unemployment rate and wage coordination. Panel models include fixed effects for countries and decades, and interactions between country fixed effects and children or female.

$* \mathrm{p}<.05, * * \mathrm{p}<.01$ 
Table 5. Multilevel Linear Regression Models of \% Occupation Female of Employees Aged 25-54: Coefficients and (Z- or T-scores).

\begin{tabular}{|c|c|c|c|c|c|c|}
\hline & $\begin{array}{c}\text { M1: } \\
\text { Female } \\
\text { Cross- } \\
\text { Section }\end{array}$ & $\begin{array}{c}\text { M2: } \\
\text { Female } \\
\text { Cross- } \\
\text { Section }\end{array}$ & $\begin{array}{c}\text { M3: Female } \\
\text { \& Male } \\
\text { Cross- } \\
\text { Section }\end{array}$ & $\begin{array}{c}\text { M4: } \\
\text { Female } \\
\text { Panel }\end{array}$ & $\begin{array}{c}\text { M5: } \\
\text { Female } \\
\text { Panel }\end{array}$ & $\begin{array}{c}\text { M6: } \\
\text { Female \& } \\
\text { Male } \\
\text { Panel }\end{array}$ \\
\hline Paid leave & $\begin{array}{c}-.0002 \\
(-.45)\end{array}$ & $\begin{array}{c}-.0002 \\
(-.41)\end{array}$ & $\begin{array}{l}-.001 \\
(-.86)\end{array}$ & $\begin{array}{l}.003 * * \\
(4.17)\end{array}$ & $\begin{array}{l}.0003 \\
(.45)\end{array}$ & $\begin{array}{c}.002 \\
(1.38)\end{array}$ \\
\hline Paid leave $^{2}$ & $\begin{array}{c}.000003 \\
(.91)\end{array}$ & $\begin{array}{c}.000002 \\
(.94)\end{array}$ & $\begin{array}{c}.000003 \\
(.73)\end{array}$ & $\begin{array}{c}-.00002 * * \\
(-3.69)\end{array}$ & $\begin{array}{c}-.000002 \\
(-.39)\end{array}$ & $\begin{array}{l}-.00001 \\
(-1.48)\end{array}$ \\
\hline Childcare Coverage & $\begin{array}{l}.001^{*} \\
(1.99)\end{array}$ & $\begin{array}{l}.001^{*} \\
(2.01)\end{array}$ & $\begin{array}{l}.001 \\
(1.56)\end{array}$ & $\begin{array}{c}-.003 * * \\
(-4.95)\end{array}$ & $\begin{array}{l}-.0001 \\
(-.20)\end{array}$ & $\begin{array}{l}-.001 \\
(-.90)\end{array}$ \\
\hline Mother & & $\begin{array}{l}.008 \\
(1.32)\end{array}$ & & & $\begin{array}{l}.010^{*} \\
(2.23)\end{array}$ & \\
\hline $\begin{array}{l}\text { Mother *Paid } \\
\text { Leave }\end{array}$ & & $\begin{array}{l}.00005 \\
(.22)\end{array}$ & & & $\begin{array}{l}.002 * \\
(2.21)\end{array}$ & \\
\hline $\begin{array}{l}\text { Mother * Paid } \\
\text { Leave }^{2}\end{array}$ & & $\begin{array}{c}-.0000004 \\
(-.34)\end{array}$ & & & $\begin{array}{c}-.00001 * \\
(-2.20)\end{array}$ & \\
\hline $\begin{array}{l}\text { Mother*Childcare } \\
\text { Coverage }\end{array}$ & & $\begin{array}{l}-.0001 \\
(-.44)\end{array}$ & & & $\begin{array}{l}.001 \\
(1.73)\end{array}$ & \\
\hline Female & & & $\begin{array}{l}.153 * * \\
(8.42)\end{array}$ & & & $\begin{array}{l}.179 * * \\
(16.52)\end{array}$ \\
\hline Female*Paid Leave & & & $\begin{array}{l}.001 \\
(.87)\end{array}$ & & & $\begin{array}{l}-.001 \\
(-.29)\end{array}$ \\
\hline $\begin{array}{l}\text { Female *Paid } \\
\text { Leave }^{2}\end{array}$ & & & $\begin{array}{c}-.000001 \\
(-.33)\end{array}$ & & & $\begin{array}{c}.000004 \\
(.37)\end{array}$ \\
\hline $\begin{array}{l}\text { Female*Childcare } \\
\text { Coverage }\end{array}$ & & & $\begin{array}{l}-.0003 \\
(-.55)\end{array}$ & & & $\begin{array}{l}-.001 \\
(-.33)\end{array}$ \\
\hline $\begin{array}{l}\mathrm{N} \\
\text { \# Countries }\end{array}$ & $\begin{array}{c}134,839 \\
21\end{array}$ & $\begin{array}{c}134,839 \\
21\end{array}$ & $\begin{array}{c}285,308 \\
21\end{array}$ & $\begin{array}{c}137,801 \\
12\end{array}$ & $\begin{array}{c}137,801 \\
12\end{array}$ & $\begin{array}{c}302,284 \\
12\end{array}$ \\
\hline
\end{tabular}

Notes: All models control for education, marital status, age and age-squared, number of children (except models 2 and 5), child under 5, and employment of other household member. Models 1 and 4 control for country-level unemployment rate and wage coordination. Panel models include fixed effects for countries and decades, and interactions between country fixed effects and children or female.

$* \mathrm{p}<.05, * * \mathrm{p}<.01$ 
Appendix I. Definitions and Sources of Dependent Variables and Country-Level Variables.

\begin{tabular}{|c|c|c|}
\hline Variable & Definition & Sources \\
\hline Employment & $\begin{array}{l}\text { binary measure of whether respondent is employed } \\
\text { or not }\end{array}$ & Luxembourg Income Study \\
\hline Annual Earnings & $\begin{array}{l}\text { respondent's labor market earnings in country-year } \\
\text { specific percentiles }\end{array}$ & Luxembourg Income Study \\
\hline $\begin{array}{l}\text { Full-Time Annual } \\
\text { Earnings }\end{array}$ & $\begin{array}{l}\text { respondent's labor market earnings in country-year } \\
\text { percentiles (among those defined by LIS as full-time; } \\
\text { or those working } 35 \text { or more hours per week; or } \\
\text { those full-time employed more than } 29 \text { weeks in year } \\
\text { and part-time employed less than } 21 \text { weeks in year) }\end{array}$ & Luxembourg Income Study \\
\hline Manager & $\begin{array}{l}\text { binary measure of whether respondent is a manager } \\
\text { or not }\end{array}$ & Luxembourg Income Study \\
\hline Lucrative Manager & $\begin{array}{l}\text { binary measure of whether respondent is manager } \\
\text { and in top } 30 \% \text { of earnings distribution }\end{array}$ & Luxembourg Income Study \\
\hline$\%$ Occ. Female & $\begin{array}{l}\text { continuous measure of percent of those employed in } \\
\text { one-digit occupations that are female }\end{array}$ & Luxembourg Income Study \\
\hline Paid Leave & $\begin{array}{l}\text { number of weeks of paid post-delivery maternity } \\
\text { leave and parental leave available to mothers }\end{array}$ & $\begin{array}{l}\text { Own data compilation from } \\
\text { national sources, Gornick et al. } \\
(1997) \text {, Gornick and Meyers } \\
\text { (2003a), Gauthier (2010), Keck and } \\
\text { Saraceno (2011), Boeckmann et al. } \\
\text { (2012) }\end{array}$ \\
\hline $\begin{array}{l}\text { Childcare } \\
\text { Coverage }\end{array}$ & $\begin{array}{l}\% \text { of children under } 3 \text { years old covered by publicly } \\
\text { subsidized childcare }\end{array}$ & $\begin{array}{l}\text { Own data compilation from } \\
\text { national sources, Gornick et al. } \\
(1997) \text {, Gornick and Meyers } \\
\text { (2003a), Gauthier (2010). Keck and } \\
\text { Saraceno (2011), Boeckmann et al. } \\
(2012)\end{array}$ \\
\hline $\begin{array}{l}\text { Unemployment } \\
\text { Rate }\end{array}$ & unemployment rate in country & Brady et al. (2014) \\
\hline $\begin{array}{l}\text { Wage } \\
\text { Coordination }\end{array}$ & $\begin{array}{l}\text { Wage Setting Coordination Scores. } 1 \text { = fragmented } \\
\text { wage bargaining, confined largely to individual firms } \\
\text { or plants; } 2 \text { = bargaining mainly at industry-level } \\
\text { with little or no pattern-setting; } 3=\text { industry-level } \\
\text { bargaining with reasonably strong pattern-setting but } \\
\text { only moderate union concentration; } 4=\text { centralized } \\
\text { bargaining by confederation(s) or government } \\
\text { imposition of wage schedule/freeze - without a peace } \\
\text { obligation, high degree of union concentration and } \\
\text { extensive, regularized pattern-setting, tacit } \\
\text { coordination of bargaining by employer } \\
\text { organizations with extensive pattern-setting; } 5= \\
\text { centralized bargaining by confederation(s) or } \\
\text { government imposition of wage schedule/freeze - } \\
\text { with a peace obligation, extremely high degree of } \\
\text { union concentration and coordination of industry } \\
\text { bargaining by confederation, extensive coordination } \\
\text { of bargaining by employer organizations with } \\
\text { extensive pattern-setting }\end{array}$ & Brady et al. (2014) \\
\hline
\end{tabular}


Appendix II. Descriptive Statistics for First Models of Recent Cross-Sections.

\begin{tabular}{|c|c|c|c|}
\hline Variable & Mean & $\overline{S S D}$ & $\overline{N N}$ \\
\hline Annual Earnings & .406 & .266 & 134,839 \\
\hline Full-Time Annual Earnings & .473 & .254 & 93,375 \\
\hline Employment & .741 & .438 & 181,995 \\
\hline Full-Time Employment & .560 & .496 & 167,423 \\
\hline Manager & .071 & .256 & 134,839 \\
\hline Lucrative Manager & .053 & .224 & 134,839 \\
\hline$\%$ Occ. Female & .563 & .162 & 134,839 \\
\hline Paid Leave & 41.648 & 43.643 & 134,839 \\
\hline Paid Leave $^{2}$ & 3639.187 & 6854.095 & 134,839 \\
\hline Childcare Coverage & 27.289 & 18.863 & 134,839 \\
\hline Unemployment Rate & 6.383 & 1.815 & 134,839 \\
\hline Wage Coordination & 2.503 & 1.417 & 134,839 \\
\hline Low Education & .152 & .359 & 134,839 \\
\hline High Education & .394 & .489 & 134,839 \\
\hline Married & .669 & .471 & 134,839 \\
\hline Age & 39.981 & 8.256 & 134,839 \\
\hline $\mathrm{Age}^{2}$ & 1666.628 & 657.566 & 134,839 \\
\hline Number of Children & 1.036 & 1.096 & 134,839 \\
\hline Child Under 5 & .221 & .415 & 134,839 \\
\hline Employed Other HH Member & .789 & .408 & 134,839 \\
\hline
\end{tabular}

Note: The descriptives for the independent variables are based on model 1 of Table 2. 
Appendix III. Multilevel Linear Regression Models of Full-Time Annual Earnings of Employees Aged 25-54: Coefficients and (Z- or T-scores).

\begin{tabular}{|c|c|c|c|c|c|c|}
\hline & $\begin{array}{c}\text { M1: } \\
\text { Female } \\
\text { Cross- } \\
\text { Section }\end{array}$ & $\begin{array}{c}\text { M2: } \\
\text { Female } \\
\text { Cross- } \\
\text { Section }\end{array}$ & $\begin{array}{c}\text { M3: Female } \\
\text { \& Male } \\
\text { Cross- } \\
\text { Section }\end{array}$ & $\begin{array}{c}\text { M4: } \\
\text { Female } \\
\text { Panel }\end{array}$ & $\begin{array}{c}\text { M5: } \\
\text { Female } \\
\text { Panel }\end{array}$ & $\begin{array}{c}\text { M6: } \\
\text { Female \& } \\
\text { Male } \\
\text { Panel }\end{array}$ \\
\hline Paid leave & $\begin{array}{l}.0001 \\
(.07)\end{array}$ & $\begin{array}{c}.001 \\
(1.36)\end{array}$ & $\begin{array}{c}-.0002 \\
(-.26)\end{array}$ & $\begin{array}{l}.036 * * \\
(2.37)\end{array}$ & $\begin{array}{l}.018 \\
(1.76)\end{array}$ & $\begin{array}{c}.008 \\
(1.55)\end{array}$ \\
\hline Paid leave $^{2}$ & $\begin{array}{c}.0000001 \\
(.02)\end{array}$ & $\begin{array}{l}-.00001 \\
(-1.37)\end{array}$ & $\begin{array}{c}.000001 \\
(.40)\end{array}$ & $\begin{array}{c}-.038^{* *} \\
(-2.56)\end{array}$ & $\begin{array}{l}-.0001 \\
(-1.49)\end{array}$ & $\begin{array}{l}-.0001 \\
(-1.85)\end{array}$ \\
\hline Childcare Coverage & $\begin{array}{c}-.0003 \\
(-.41)\end{array}$ & $\begin{array}{l}-.0003 \\
(-.36)\end{array}$ & $\begin{array}{l}.0004 \\
(.79)\end{array}$ & $\begin{array}{c}-.0003 * \\
(-2.06)\end{array}$ & $\begin{array}{c}-.018 \\
(-1.94)\end{array}$ & $\begin{array}{l}-.007 \\
(-1.36)\end{array}$ \\
\hline $\begin{array}{l}\text { \% Women in } \\
\text { Occupation }\end{array}$ & $\begin{array}{l}-.126 * * \\
(-27.15)\end{array}$ & $\begin{array}{l}-.125^{* *} \\
(-26.96)\end{array}$ & $\begin{array}{l}-.015^{* *} \\
(-5.78)\end{array}$ & $\begin{array}{l}-.097 * \\
(-3.01)\end{array}$ & $\begin{array}{l}-.097 * \\
(-2.97)\end{array}$ & $\begin{array}{l}.002 \\
(.09)\end{array}$ \\
\hline Mother & & $\begin{array}{l}-.003 \\
(-.24)\end{array}$ & & & $\begin{array}{c}-.024 \\
(-1.89)\end{array}$ & \\
\hline $\begin{array}{l}\text { Mother *Paid } \\
\text { Leave }\end{array}$ & & $\begin{array}{l}-.002 * * \\
(-3.57)\end{array}$ & & & $\begin{array}{c}.004 \\
(1.98)\end{array}$ & \\
\hline $\begin{array}{l}\text { Mother *Paid } \\
\text { Leave }^{2}\end{array}$ & & $\begin{array}{c}.00001^{* *} \\
(3.64)\end{array}$ & & & $\begin{array}{l}-.0001 \\
(-1.38)\end{array}$ & \\
\hline $\begin{array}{l}\text { Mother *Childcare } \\
\text { Coverage }\end{array}$ & & $\begin{array}{l}.001 \\
(.20)\end{array}$ & & & $\begin{array}{l}-.0001 \\
(-.03)\end{array}$ & \\
\hline Female & & & $\begin{array}{c}-.122 * * * \\
(-5.88)\end{array}$ & & & $\begin{array}{l}-.122 * * \\
(-15.24)\end{array}$ \\
\hline Female*Paid Leave & & & $\begin{array}{l}.001 \\
(.71)\end{array}$ & & & $\begin{array}{l}.008^{*} \\
(4.38)\end{array}$ \\
\hline $\begin{array}{l}\text { Female *Paid } \\
\text { Leave }^{2}\end{array}$ & & & $\begin{array}{c}-.000004 \\
(-.90)\end{array}$ & & & $\begin{array}{l}-.0001^{*} \\
(-2.53)\end{array}$ \\
\hline $\begin{array}{l}\text { Female*Childcare } \\
\text { Coverage }\end{array}$ & & & $\begin{array}{l}-.001 \\
(-1.39)\end{array}$ & & & $\begin{array}{l}-.003^{*} \\
(-2.49)\end{array}$ \\
\hline $\begin{array}{l}\mathrm{N} \\
\text { \# Countries }\end{array}$ & $\begin{array}{c}93,375 \\
19\end{array}$ & $\begin{array}{c}93,375 \\
19\end{array}$ & $\begin{array}{c}218,220 \\
19\end{array}$ & $\begin{array}{c}90,930 \\
11\end{array}$ & $\begin{array}{c}90,930 \\
11\end{array}$ & $\begin{array}{c}217,514 \\
11\end{array}$ \\
\hline
\end{tabular}

Notes: All models control for education, marital status, age and age-squared, number of children (except models 2 and 5), child under 5, and employment of other household member. Models 1 and 4 control for country-level unemployment rate and wage coordination. Panel models include fixed effects for countries and decades, and interactions between country fixed effects and children or female.

$* \mathrm{p}<.05, * * \mathrm{p}<.01$ 
Appendix IV. Multilevel Logistic Regression Models of Full-Time Employment of People Aged 25-54: Coefficients and (Z-scores).

\begin{tabular}{|c|c|c|c|c|c|c|}
\hline & $\begin{array}{c}\text { M1: } \\
\text { Female } \\
\text { Cross- } \\
\text { Section }\end{array}$ & $\begin{array}{c}\text { M2: } \\
\text { Female } \\
\text { Cross- } \\
\text { Section }\end{array}$ & $\begin{array}{c}\text { M3: } \\
\text { Female } \\
\text { \& Male } \\
\text { Cross- } \\
\text { Section }\end{array}$ & $\begin{array}{c}\text { M4: } \\
\text { Female } \\
\text { Panel }\end{array}$ & $\begin{array}{c}\text { M5: Female } \\
\text { Panel }\end{array}$ & $\begin{array}{c}\text { M6: } \\
\text { Female \& } \\
\text { Male } \\
\text { Panel }\end{array}$ \\
\hline Paid leave & $\begin{array}{l}.003 \\
(.25)\end{array}$ & $\begin{array}{l}.007 \\
(.65)\end{array}$ & $\begin{array}{l}-.004 \\
(-.40)\end{array}$ & $\begin{array}{l}.174 * * \\
(12.66)\end{array}$ & $\begin{array}{l}.088 * * \\
(3.71)\end{array}$ & $\begin{array}{l}.047 * * \\
(2.75)\end{array}$ \\
\hline Paid leave $^{2}$ & $\begin{array}{c}.000004 \\
(.06)\end{array}$ & $\begin{array}{c}-.00001 \\
(-.19)\end{array}$ & $\begin{array}{c}.000003 \\
(.04)\end{array}$ & $\begin{array}{l}-.001^{* *} \\
(-13.42)\end{array}$ & $\begin{array}{l}-.001 * * \\
(-4.08)\end{array}$ & $\begin{array}{l}-.0004^{*} \\
(-2.37)\end{array}$ \\
\hline Childcare Coverage & $\begin{array}{l}.011 \\
(1.25)\end{array}$ & $\begin{array}{l}-.004 \\
(-.46)\end{array}$ & $\begin{array}{l}-.015 \\
(-1.47)\end{array}$ & $\begin{array}{l}-.148^{* *} \\
(-10.15)\end{array}$ & $\begin{array}{l}-.052 * \\
(-2.53)\end{array}$ & $\begin{array}{l}-.039 * * \\
(-3.38)\end{array}$ \\
\hline Mother & & $\begin{array}{l}-.661^{* *} \\
(-31.69)\end{array}$ & & & $\begin{array}{l}-.521^{* *} \\
(-6.28)\end{array}$ & \\
\hline Mother*Paid Leave & & $\begin{array}{l}-.015^{* *} \\
(-14.38)\end{array}$ & & & $\begin{array}{l}-.017^{*} \\
(-2.32)\end{array}$ & \\
\hline $\begin{array}{l}\text { Mother* Paid } \\
\text { Leave }^{2}\end{array}$ & & $\begin{array}{l}.0001 * * \\
(12.82)\end{array}$ & & & $\begin{array}{l}.0002 \\
(1.40)\end{array}$ & \\
\hline $\begin{array}{l}\text { Mother*Childcare } \\
\text { Coverage }\end{array}$ & & $\begin{array}{l}.024 * * * \\
(27.66)\end{array}$ & & & $\begin{array}{l}.016 \\
(1.21)\end{array}$ & \\
\hline Female & & & $\begin{array}{c}-2.396 * * \\
(-6.14)\end{array}$ & & & $\begin{array}{c}-1.513 * * \\
(-29.30)\end{array}$ \\
\hline Female*Paid Leave & & & $\begin{array}{l}.003 \\
(.21)\end{array}$ & & & $\begin{array}{l}.004 \\
(.90)\end{array}$ \\
\hline $\begin{array}{l}\text { Female *Paid } \\
\text { Leave }^{2}\end{array}$ & & & $\begin{array}{c}.00003 \\
(.36)\end{array}$ & & & $\begin{array}{c}-.00001 \\
(-.05)\end{array}$ \\
\hline $\begin{array}{l}\text { Female*Childcare } \\
\text { Coverage }\end{array}$ & & & $\begin{array}{l}.024 \\
(1.85)\end{array}$ & & & $\begin{array}{l}.019^{*} \\
(2.08)\end{array}$ \\
\hline $\begin{array}{l}\mathrm{N} \\
\text { \# Countries }\end{array}$ & $\begin{array}{c}167,423 \\
19 \\
\end{array}$ & $\begin{array}{c}167,423 \\
19 \\
\end{array}$ & $\begin{array}{c}326,177 \\
19 \\
\end{array}$ & $\begin{array}{c}167,205 \\
11 \\
\end{array}$ & $\begin{array}{c}167,205 \\
11 \\
\end{array}$ & $\begin{array}{c}327,438 \\
11 \\
\end{array}$ \\
\hline
\end{tabular}

Notes: All models control for education, marital status, age and age-squared, number of children (except models 2 and 5), child under 5, and employment of other household member. Models 1 and 4 control for country-level unemployment rate and wage coordination. Panel models include fixed effects for countries and decades, and interactions between country fixed effects and children or female.

$* \mathrm{p}<.05, * * \mathrm{p}<.01$ 
Appendix V. Multilevel Logistic Regression Models of Being a Lucrative Manager Among Employees Aged 25-54: Co6fficients and (Z-scores).

\begin{tabular}{|c|c|c|c|c|c|c|}
\hline & $\begin{array}{c}\text { M1: } \\
\text { Female } \\
\text { Cross- } \\
\text { Section }\end{array}$ & $\begin{array}{c}\text { M2: } \\
\text { Female } \\
\text { Cross- } \\
\text { Section }\end{array}$ & $\begin{array}{c}\text { M3: Female } \\
\text { \& Male } \\
\text { Cross- } \\
\text { Section }\end{array}$ & $\begin{array}{c}\text { M4: } \\
\text { Female } \\
\text { Panel }\end{array}$ & $\begin{array}{c}\text { M5: } \\
\text { Female } \\
\text { Panel }\end{array}$ & $\begin{array}{c}\text { M6: } \\
\text { Female \& } \\
\text { Male } \\
\text { Panel }\end{array}$ \\
\hline Paid leave & $\begin{array}{l}-.034 * \\
(-2.41)\end{array}$ & $\begin{array}{l}-.025 \\
(-1.78)\end{array}$ & $\begin{array}{l}-.024^{*} \\
(-2.22)\end{array}$ & $\begin{array}{l}-.074 \\
(-1.92)\end{array}$ & $\begin{array}{l}-.054 \\
(-1.49)\end{array}$ & $\begin{array}{l}-.076^{* *} \\
(-2.84)\end{array}$ \\
\hline Paid leave $^{2}$ & $\begin{array}{l}.0002^{* *} \\
(2.64)\end{array}$ & $\begin{array}{l}.0002 * \\
(1.99)\end{array}$ & $\begin{array}{l}.0001^{*} \\
(2.40)\end{array}$ & $\begin{array}{l}.0005^{*} \\
(2.14)\end{array}$ & $\begin{array}{l}.0004 \\
(1.81)\end{array}$ & $\begin{array}{c}.0005^{* *} \\
(2.86)\end{array}$ \\
\hline Childcare Coverage & $\begin{array}{l}-.015 \\
(-1.20)\end{array}$ & $\begin{array}{l}-.019 \\
(-1.38)\end{array}$ & $\begin{array}{l}-.009 \\
(-.87)\end{array}$ & $\begin{array}{l}.030 \\
(.80)\end{array}$ & $\begin{array}{l}-.007 \\
(-.21)\end{array}$ & $\begin{array}{l}.039^{*} \\
(2.47)\end{array}$ \\
\hline Mother & & $\begin{array}{l}-.193 \\
(-1.51)\end{array}$ & & & $\begin{array}{c}-.453 * * \\
(-4.96)\end{array}$ & \\
\hline $\begin{array}{l}\text { Mother *Paid } \\
\text { Leave }\end{array}$ & & $\begin{array}{l}-.008 \\
(-1.54)\end{array}$ & & & $\begin{array}{l}-.003 \\
(-.18)\end{array}$ & \\
\hline $\begin{array}{l}\text { Mother *Paid } \\
\text { Leave }^{2}\end{array}$ & & $\begin{array}{l}.0001 \\
(1.67)\end{array}$ & & & $\begin{array}{l}.00002 \\
(-.18)\end{array}$ & \\
\hline $\begin{array}{l}\text { Mother *Childcare } \\
\text { Coverage }\end{array}$ & & $\begin{array}{l}.002 \\
(.48)\end{array}$ & & & $\begin{array}{l}.031 \\
(1.79)\end{array}$ & \\
\hline Female & & & $\begin{array}{l}-.738^{* *} \\
(-3.43)\end{array}$ & & & $\begin{array}{l}-.341^{* *} \\
(-5.07)\end{array}$ \\
\hline Female*Paid Leave & & & $\begin{array}{l}-.005 \\
(.68)\end{array}$ & & & $\begin{array}{l}.018 \\
(1.70)\end{array}$ \\
\hline $\begin{array}{l}\text { Female *Paid } \\
\text { Leave }^{2}\end{array}$ & & & $\begin{array}{l}.00004 \\
(.83)\end{array}$ & & & $\begin{array}{l}-.0001 \\
(-1.22)\end{array}$ \\
\hline $\begin{array}{l}\text { Female*Childcare } \\
\text { Coverage }\end{array}$ & & & $\begin{array}{l}-.009 \\
(-1.15)\end{array}$ & & & $\begin{array}{l}-.028^{*} \\
(-2.32)\end{array}$ \\
\hline $\begin{array}{l}\mathrm{N} \\
\text { \# Countries }\end{array}$ & $\begin{array}{c}134,839 \\
21\end{array}$ & $\begin{array}{c}134,839 \\
21\end{array}$ & $\begin{array}{c}285,308 \\
21\end{array}$ & $\begin{array}{c}137,801 \\
12\end{array}$ & $\begin{array}{c}137,801 \\
12\end{array}$ & $\begin{array}{c}302,284 \\
12\end{array}$ \\
\hline
\end{tabular}

Notes: All models control for education, marital status, age and age-squared, number of children (except models 2 and 5), child under 5, and employment of other household member. Models 1 and 4 control for country-level unemployment rate and wage coordination. Panel models include fixed effects for countries and decades, and interactions between country fixed effects and children or female.

$* \mathrm{p}<.05, * * \mathrm{p}<.01$ 
Appendix VI. Code for Data and Analyses.

*The following is code for the example of Denmark 2004, similar code was written for all country-years, and then all country-years were pooled*

use $\$ \mathrm{dk} 04 \mathrm{~h}$, clear

sort hid

keep all

save \$mydata/[identifying]/den04h, replace

use $\$ \mathrm{dk} 04 \mathrm{p}$, clear

sort hid

keep all

save \$mydata/[identifying]/den04p, replace

merge m:1 hid using \$mydata/[identifying]/den04h, keep(match) nogen

*SEX OF RESPONDENT*

recode sex $(1=0)(2=1)(.=)$, gen(female)

recode $\operatorname{sex}(1=1)(2=0)(.=$.$) , gen ($ male $)$

*WORKING-AGED RESPONDENT*

gen adult2 $=0$

replace adult $2=1$ if inrange(age, 25,54$)$

replace adult $2=$. if age $==$.

*EMPLOYMENT=EMP*

*FULL-TIME*

gen fulltime $=0$ if emp! $=$.

replace fulltime $=1$ (hours $>=35 \mid$ fyft $==1$ ) $\&$ emp $==1$

replace fulltime $=1$ if weeksft $>29 \&$ emp $==1$

*EARNINGS=PIL*

*MANAGER*

gen $\mathrm{mgr}=0$ if emp $==1$

replace $\mathrm{mgr}=1$ if occb $1==1$

*LUCRATIVE MANAGER*

egen pctpil70 $=$ pctile(pil), $\mathrm{p}(70)$

gen above $70=$ pil $>$ pctpil70

gen lucmgr $2=0$ if $\mathrm{emp}==1$

replace lucmgr $2=1$ if $m g r==1 \&$ above $70==1$

*OCCUPATION \% FEMALE*

egen pfemocc $=$ mean $($ female $)$, by $($ occb1)

*EDUCATION*

gen plowed $=0$ if educ! $=$.

replace plowed $=1$ if educ $==1$

gen phighed $=0$ if educ! $=$.

replace phighed $=1$ if educ $=3$

*MARRIED*

gen married $=$.

replace married $=1$ if marital $<200$ 
replace married $=0$ if marital $>=200$

*AGE*

gen pagesq $=$ age $^{\wedge} 2$

*SOMEONE ELSE IN HH EMPLOYED*

gen othemp $=0$

replace othemp $=1$ if nearn-emp $>0$

replace othemp $=$. if nearn $==$. $\mid \mathrm{emp}==$.

*BINARY FOR CHILDREN IN HH*

gen kids $=0$ if nhhmem $17 !=$.

replace kids $=1$ if nhhmem $17>0$

*macro-level variables*

gen recent $=1$

gen panel $=1$

gen country $=6$

gen decade $=3$

gen ml_weeks $=18$

gen $\mathrm{ml}$-pay_rate $=90$

gen pale_weeks $1=32$

gen pale_weeks $2=0$

gen leave_post $=46$

gen leave_paid $=46$

gen leave_paid $2=$ leave_paid ${ }^{\wedge} 2$

gen cc_covrate $2=57.1$

gen cc_covrate $5=93$

gen $\mathrm{ud}=71.71149$

gen unempr $=5.5$

gen wcoord $=4$

gen kidleave $=$ kids* leave_paid

gen kidcc=kids*cc_covrate2

gen femleave $=$ female*leave_paid

gen femcc $=$ female*cc_covrate 2

gen kidleavesq= leave_paid $2 *$ kids

gen femleavesq $=$ leave_paid $2 *$ female

*ADDITIONAL WORK DONE AFTER MERGING EACH COUNTRY-YEAR INTO ONE FILE*

*Convert Earnings to Percentiles*

gen sample $=0$

replace sample $=1$ if emp $==1 \&$ pil! $=. \&$ kids! $=. \&$ plowed!=. \& phighed!=. \&

married!=.\& age $!=. \&$ othemp! $=. \&$ adult $2==1$

by did, sort: egen $n$ did $=$ count(pil) if sample $==1$

by did,: egen $\mathrm{i}=\operatorname{rank}(\mathrm{pil})$ if sample $==1$

gen pctpil $=\mathrm{i} /(\mathrm{ndid}+1)$ if $\mathrm{emp}==1 \&$ sample $==1$

*Samples Omitting Israel*

gen recent $2=$ recent

replace recent $2=0$ if $\mathrm{did}==194$

gen panel $2=$ panel

replace panel $2=0$ if $\mathrm{did}==194$

replace panel $2=0$ if $\mathrm{did}==17$ 
*Generating young child binary variable*

gen ykid=nhhmem5

replace ykid $=1$ if nhhmem5 $>1 \&$ nhhmem5!=.

\section{*Table 2. Earnings (PCTPIL2) Models}

xtmixed pctpil2 leave_paid leave_paid2 cc_covrate2 poccfem unempr wcoord plowed phighed married age pagesq ykid nhhmem 17 othemp if emp==1 \& recent==1 \& adult $2==1 \&$ female==1 $\|$ did:,

xtmixed pctpil2 leave_paid leave_paid2 cc_covrate2 poccfem kids kidleave kidleavesq kidcc plowed phighed married age pagesq ykid othemp if $\mathrm{emp}==1 \&$ recent $==1 \&$ adult $2==1 \&$ female $==1 \|$ did: kids,

xtmixed pctpil2 leave_paid leave_paid 2 cc_covrate2 poccfem female femleave femleavesq femcc plowed phighed married age pagesq ykid nhhmem17 othemp if emp==1 \& recent==1 \& adult $2==1 \|$ did: female,

reg pctpil2 leave_paid cc_covrate2 leave_paid2 poccfem unempr wcoord plowed phighed married age pagesq ykid nhhmem 17 othemp i.country i.decade if $\mathrm{emp}==1 \&$ panel $==1 \&$ adult $2==1 \&$ female $==1$, robust cluster(country)

reg pctpil2 leave_paid leave_paid2 cc_covrate2 poccfem kids kidleave kidleavesq kidcc plowed phighed married age pagesq ykid othemp i.country kids $\#$ i.country i.decade if $\mathrm{emp}==1 \&$ panel $==1 \&$ adult $2==1 \&$ female $==1$, robust cluster(country)

reg pctpil2 leave_paid leave_paid 2 cc_covrate 2 poccfem female femleave femleavesq femcc plowed phighed married age pagesq ykid nhhmem 17 othemp i.country female\#i.country i.decade if emp $==1 \&$ panel $==1 \&$ adult $2==1$, robust cluster(country)

*Appendix III. Full-Time Earnings Models

xtmixed pctpil2 leave_paid leave_paid2 cc_covrate2 poccfem unempr wcoord plowed phighed married age pagesq ykid nhhmem 17 othemp if emp $==1 \&$ fulltime= $=1$ \& recent==1 \& adult $2==1 \&$ female==1 $\|$ did:,

xtmixed pctpil2 leave_paid leave_paid2 cc_covrate2 poccfem kids kidleave kidleavesq kidcc plowed phighed married age pagesq ykid othemp if emp $==1 \&$ fulltime $==1 \&$ recent $==1 \&$ adult $2==1 \&$ female= $=1 \|$ did: kids,

xtmixed pctpil2 leave_paid leave_paid 2 cc_covrate2 poccfem female femleave femleavesq femcc plowed phighed married age pagesq ykid nhhmem 17 othemp if emp $==1 \&$ fulltime $==1 \&$ recent $==1 \&$ adult $2==1$ |did: female,

reg pctpil2 leave_paid cc_covrate2 leave_paid2 poccfem unempr wcoord plowed phighed married age pagesq nhhmem 17 ykid othemp i.country i.decade if emp $==1 \&$ fulltime $==1 \&$ panel $==1 \&$ adult $2==1 \&$ female $==1$, robust cluster(country)

reg pctpil2 leave_paid leave_paid 2 cc_covrate2 poccfem kids kidleave kidleavesq kidcc plowed phighed married age pagesq ykid othemp i.country kids $\#$ i.country i.decade if emp==1\& fulltime $==1 \&$ panel $==1 \&$ adult $2==1 \&$ female $==1$, robust cluster(country)

reg pctpil2 leave_paid leave_paid2 cc_covrate2 poccfem female femleave femleavesq femcc plowed phighed married age pagesq nhhmem 17 ykid othemp i.country female\#i.country i.decade if emp $=1 \&$ fulltime $==1 \&$ panel $==1 \&$ adult $2==1$, robust cluster(country)

\section{Table 3. Employment}

xtmelogit emp leave_paid leave_paid 2 cc_covrate 2 unempr wcoord plowed phighed married age pagesq nhhmem 17 ykid othemp if recent $==1 \&$ adult $2==1 \&$ female $==1 \mid$ did: , lap 
xtmelogit emp leave_paid leave_paid2 cc_covrate2 kids kidleave kidleavesq kidcc plowed phighed married age pagesq ykid othemp if recent $==1 \&$ adult $2==1 \&$ female $==1 \|$ did: kids, lap

xtmelogit emp leave_paid leave_paid 2 cc_covrate 2 female femleave femleavesq femcc plowed phighed married age pagesq nhhmem 17 ykid othemp if recent $==1 \&$ adult $2==1 \|$ did: female, lap

logit emp leave_paid leave_paid 2 cc_covrate 2 unempr wcoord plowed phighed married age pagesq nhhmem17 ykid othemp i.country i.decade if panel $==1 \&$ adult $2==1 \&$ female $==1$, robust cluster(country)

logit emp leave_paid leave_paid2 cc_covrate2 kids kidleave kidleavesq kidcc plowed phighed married age pagesq ykid othemp i.country kids\#i.country i.decade if panel $==1 \&$ adult $2==1 \&$ female $==1$, robust cluster(country)

logit emp leave_paid leave_paid 2 cc_covrate2 female femleave femleavesq femcc plowed phighed married age pagesq nhhmem17 ykid othemp i.country female\#i.country i.decade if panel $==1 \&$ adult $2==1$, robust cluster(country)

\section{Appendix IV: Full-Time Employment}

xtmelogit fulltime leave_paid leave_paid2 cc_covrate2 unempr wcoord plowed phighed married age pagesq nhhmem 17 ykid othemp if recent $==1 \&$ adult $2==1 \&$ female $==1 \|$ did: female, lap

xtmelogit fulltime leave_paid leave_paid2 cc_covrate2 kids kidleave kidleavesq kidcc plowed phighed married age pagesq ykid othemp if recent $==1 \&$ adult $2==1 \&$ female $==1 \|$ did: female, lap

xtmelogit fulltime leave_paid leave_paid2 cc_covrate2 female femleave femleavesq femcc plowed phighed married age pagesq $n h h m e m 17$ ykid othemp if recent $==1 \&$ adult $2==1 \|$ did: female, lap

logit fulltime leave_paid leave_paid 2 cc_covrate 2 unempr wcoord plowed phighed married age pagesq nhhmem17 ykid othemp i.country i.decade if panel $==1 \&$ adult $2==1 \&$ female $==1$, robust cluster(country)

logit fulltime leave_paid leave_paid2 cc_covrate2 kids kidleave kidleavesq kidcc plowed phighed married age pagesq ykid othemp i.country kids\#i.country i.decade if panel $==1 \&$ adult $2==1 \&$ female $==1$, robust cluster(country)

logit fulltime leave_paid leave_paid2 cc_covrate2 female femleave femleavesq femcc plowed phighed married age pagesq nhhmem 17 ykid othemp i.country female\#i.country i.decade if panel $==1 \&$ adult $2==1$, robust cluster(country)

\section{Table 4. Manager Models}

xtmelogit mgr leave_paid leave_paid 2 cc_covrate2 unempr wcoord plowed phighed married age pagesq nhhmem 17 ykid othemp if $\mathrm{emp}==1 \&$ recent $==1 \&$ adult $2==1 \&$ female $==1 \|$ did: female, lap

xtmelogit mgr leave_paid leave_paid2 cc_covrate2 kids kidleave kidleavesq kidcc plowed phighed married age pagesq ykid othemp if recent $==1 \&$ adult $2==1 \&$ female $==1 \|$ did: kids, lap

xtmelogit mgr leave_paid leave_paid 2 cc_covrate 2 female femleave femleavesq femcc plowed phighed married age pagesq nhhmem 17 ykid othemp if emp $==1 \&$ recent $==1 \&$ adult $2==1 \|$ did: female, lap

logit mgr leave_paid leave_paid2 cc_covrate 2 unempr wcoord plowed phighed married age pagesq nhhmem17 ykid othemp i.country i.decade if $\mathrm{emp}==\overline{1} \&$ panel $==1 \&$ adult $2==1 \&$ female==1, robust cluster(country)

logit mgr leave_paid leave_paid2 cc_covrate2 kids kidleave kidleavesq kidcc plowed phighed married age pagesq ykid othemp i.country kids $\#$ i.country i.decade if $\mathrm{emp}==1 \&$ panel $==1 \&$ adult $2==1 \&$ female $==1$, robust cluster(country) 
logit mgr leave_paid leave_paid 2 cc_covrate2 female femleave femleavesq femcc plowed phighed married age pagesq nhhmem17 ykid othemp i.country female\#i.country i.decade if emp==1\& panel==1\& adult $2==1$, robust cluster(country)

\section{Appendix V. Lucrative Manager Models}

xtmelogit lucmgr2 leave_paid leave_paid2 cc_covrate2 unempr wcoord plowed phighed married age pagesq nhhmem 17 ykid othemp if emp $==1 \&$ recent $==1 \&$ adult $2==1 \&$ female $==1 \|$ did: female, lap

xtmelogit lucmgr2 leave_paid leave_paid2 cc_covrate2 kids kidleave kidleavesq kidcc plowed phighed married age pagesq ykid othemp if recent $==1 \&$ adult $2==1 \&$ female $==1 \|$ did: kids, lap

xtmelogit lucmgr2 leave_paid leave_paid 2 cc_covrate2 female femleave femleavesq femcc plowed phighed married age pagesq nhhmem 17 ykid othemp if emp $==1 \&$ recent $==1 \&$ adult $2==1 \|$ did: female, lap

logit lucmgr2 leave_paid leave_paid 2 cc_covrate2 unempr wcoord plowed phighed married age pagesq nhhmem17 ykid othemp i.country i.decade if $\mathrm{emp}==1 \&$ panel $==1 \&$ adult $2==1 \&$ female $==1$, robust cluster(country)

logit lucmgr2 leave_paid leave_paid2 cc_covrate2 kids kidleave kidleavesq kidcc plowed phighed married age pagesq ykid othemp i.country kids\#i.country i.decade if $\mathrm{emp}==1 \&$ panel $==1 \&$ adult $2==1 \&$ female $==1$, robust cluster(country)

logit lucmgr2 leave_paid leave_paid2 cc_covrate2 female femleave femleavesq femcc plowed phighed married age pagesq nhhmem 17 ykid othemp i.country female\#i.country i.decade if emp==1 \& panel==1 \& adult $2==1$, robust cluster(country)

Table 5. \% Female in Occupation Dependent Variable Models

xtmixed poccfem leave_paid leave_paid2 cc_covrate2 unempr wcoord plowed phighed married age pagesq nhhmem 17 ykid othemp if emp $==1 \&$ recent $==1 \&$ adult $2==1 \&$ female $==1 \|$ did:,

xtmixed poccfem leave_paid leave_paid 2 cc_covrate2 kids kidleave kidleavesq kidcc plowed phighed married age pagesq ykid othemp if emp $=1 \&$ recent $==1 \&$ adult $2==1 \&$ female $==1 \|$ did: kids,

xtmixed poccfem leave_paid leave_paid 2 cc_covrate 2 female femleave femleavesq femcc plowed phighed married age pagesq nhhmem 17 ykid othemp if emp $==1 \&$ recent $==1 \&$ adult $2==1 \|$ did: female,

reg poccfem leave_paid leave_paid 2 cc_covrate 2 unempr wcoord plowed phighed married age pagesq nhhmem17 ykid othemp i.country i.decade if $\mathrm{emp}==1 \&$ panel $==1 \&$ adult $2==1 \&$ female==1, robust cluster(country)

reg poccfem leave_paid leave_paid2 cc_covrate2 kids kidleave kidleavesq kidcc plowed phighed married age pagesq ykid othemp i.country kids\#i.country i.decade if $\mathrm{emp}==1 \&$ panel $==1 \&$ adult $2==1 \&$ female $==1$, robust cluster(country)

reg poccfem leave_paid leave_paid2 cc_covrate2 female femleave femleavesq femcc plowed phighed married age pagesq nhhmem 17 ykid othemp i.country female\#i.country i.decade if emp $==1 \&$ panel $==1 \&$ adult $2==1$, robust cluster(country) 